Atmos. Chem. Phys., 17, 12509-12531, 2017

https://doi.org/10.5194/acp-17-12509-2017

(c) Author(s) 2017. This work is distributed under

the Creative Commons Attribution 3.0 License.

\title{
Modelling organic aerosol concentrations and properties during ChArMEx summer campaigns of 2012 and 2013 in the western Mediterranean region
}

\author{
Mounir Chrit $^{1}$, Karine Sartelet ${ }^{1}$, Jean Sciare ${ }^{2,7}$, Jorge Pey ${ }^{3, \text { a }}$, Nicolas Marchand ${ }^{3}$, Florian Couvidat ${ }^{4}$, \\ Karine Sellegri ${ }^{5}$, and Matthias Beekmann ${ }^{6}$ \\ ${ }^{1}$ CEREA, Joint Laboratory École des Ponts ParisTech - EDF R\&D, Université Paris-Est, 77455 Champs-sur-Marne, France \\ ${ }^{2}$ LSCE, CNRS-CEA-UVSQ, IPSL, Université Paris-Saclay, Gif-sur-Yvette, France \\ ${ }^{3}$ Aix-Marseille University, CNRS, LCE UMR 7376, Marseille, France \\ ${ }^{4}$ INERIS, Verneuil-en-Halatte, France \\ ${ }^{5}$ Laboratoire de Météorologie Physique (LaMP), UMR 6016 CNRS/UBP, of the Observatoire de Physique du Globe de \\ Clermont-Ferrand (OPGC), Aubière, France \\ ${ }^{6}$ LISA, UMR CNRS 7583, IPSL, Université Paris-Est Créteil and Université Paris Diderot, France \\ ${ }^{7}$ EEWRC, The Cyprus Institute, Nicosia, Cyprus \\ ${ }^{a}$ now at: The Geological Survey of Spain, IGME, 50006 Zaragoza, Spain
}

Correspondence to: Mounir Chrit (mounir.chrit@enpc.fr)

Received: 4 April 2017 - Discussion started: 29 May 2017

Revised: 25 August 2017 - Accepted: 15 September 2017 - Published: 23 October 2017

\begin{abstract}
In the framework of the Chemistry-Aerosol Mediterranean Experiment, a measurement site was set up at a remote site (Ersa) on Corsica Island in the northwestern Mediterranean Sea. Measurement campaigns performed during the summers of 2012 and 2013 showed high organic aerosol concentrations, mostly from biogenic origin. This work aims to represent the organic aerosol concentrations and properties (oxidation state and hydrophilicity) using the air-quality model Polyphemus with a surrogate approach for secondary organic aerosol (SOA) formation. Biogenic precursors are isoprene, monoterpenes and sesquiterpenes. In this work, the following model oxidation products of monoterpenes are added: (i) a carboxylic acid (MBTCA) to represent multi-generation oxidation products in the low$\mathrm{NO}_{x}$ regime, (ii) organic nitrate chemistry and (iii) extremely low-volatility organic compounds (ELVOCs) formed by ozonolysis. The model shows good agreement of measurements of organic concentrations for both 2012 and 2013 summer campaigns. The modelled oxidation property and hydrophilic organic carbon properties of the organic aerosols also agree reasonably well with the measurements. The influence of the different chemical processes added to the model on the oxidation level of organics is studied. Measured and
\end{abstract}

simulated water-soluble organic carbon (WSOC) concentrations show that even at a remote site next to the sea, about $64 \%$ of the organic carbon is soluble. The concentrations of WSOC vary with the origins of the air masses and the composition of organic aerosols. The marine organic emissions only contribute to a few percent of the organic mass in $\mathrm{PM}_{1}$, with maxima above the sea.

\section{Introduction}

The Mediterranean region is considered as one of the most prominent regions to be detrimentally impacted by climate and air composition changes over both southern Europe and northern Africa. Organic aerosols (OA) account for about $20-50 \%$ of the fine aerosol mass at continental mid-latitudes (Saxena and Hildemann, 1996) and as high as $90 \%$ in tropical forest areas (Kanakidou et al., 2005; Jimenez et al., 2009). They contribute to more than $50 \%$ of EU-regulated $\mathrm{PM}_{2.5}$ concentrations in Europe (Putaud et al., 2004). OA affect both climate and human health. They influence the radiation budget by mostly scattering sunlight resulting in negative direct radiative forcing (Fuzzi et al., 2006; Lin et al., 2014). 
Moreover, hydrophilic OA can act as a cloud condensation nuclei and hence modify cloud microphysical properties and lifetime. In terms of health effects, OA toxicity is linked to the oxidative stress which is induced by the reactive oxygen species. The oxidative potential may differ for the different organic precursors (Rattanavaraha et al., 2011; Jiang et al., 2016; Tuet et al., 2017).

$\mathrm{OA}$ are usually classified either as primary (POA) or secondary (SOA). POA are directly emitted in the atmosphere, often as intermediate/semivolatile organic compounds (I/SVOCs), which partition between the gas and the particle phases (Robinson et al., 2007). The gas phase of I/S-VOC is missing from emission inventories (Couvidat et al., 2012; Kim et al., 2016). SOA are produced through chemical oxidation of volatile organic compounds (VOCs) and I/S-VOCs and through condensation of I/S-VOCs.

A large fraction of emitted VOCs is biogenic, especially in the western Mediterranean in summer, when solar radiation is high. Biogenic emissions may age and form SOA as they are transported through different environments (Hayes et al., 2015). Using aerosol mass spectrometer (AMS) measurements performed in an urban area in southern France (Marseille) and positive matrix factorisation techniques, El Haddad et al. $(2011,2013)$ attributed $80 \%$ of the organic aerosol mass to biogenic secondary organic aerosols (BSOA) and near $40 \%$ of the BSOA to monoterpene oxidation products. These high biogenic concentrations in an urban area may be partly explained by the influence of anthropogenic emissions on biogenic SOA formation (Carlton et al., 2010; Hoyle et al., 2011; Sartelet et al., 2012).

Similar results were obtained through measurement campaigns in the Barcelona region (Spain), where Minguillón et al. $(2011,2016)$ have found a prevalence of non-fossil organic aerosol sources in remote and urban environments and clear evidence of biogenic VOC oxidation products and biogenic SOA formation under anthropogenic stressors.

The ChArMEx (Chemistry and Aerosol Mediterranean Experiment: http://charmex.lsce.ipsl.fr) project has organised several summer campaigns to study atmospheric chemistry and its impacts in the western Mediterranean region. The TRAQA (Transport et Qualité de l'Air) campaign was set up in summer 2012 to study the transport and impact of continental air on atmospheric pollution over the basin (Sič et al., 2016). The ADRIMED (Aerosol Direct Radiative Impact in the Mediterranean; Mallet et al. (2016)) campaign was set up in June-July 2013 to assess the radiative impact of aerosols, while the SAF-MED (Secondary Aerosol Formation in the MEDiterranean) campaign was set up in Julyearly August 2013 to understand and characterise the concentrations and properties of organic aerosols in the western Mediterranean and to figure out the origins of the high concentrations observed outside urban areas. Intensive groundbased in situ measurements were performed during the summer of 2013, while airborne measurements were performed during the summers 2013 and 2014 (Di Biagio et al., 2015;
Freney et al., 2017). In agreement with the observations of El Haddad et al. (2013) in Marseille on the French Mediterranean coast, the ground-based in situ measurements performed at the remote site of Ersa on Cape Corsica, the northern tip of Corsica Island (southeast of continental France) showed that OA are mostly from biogenic origin. However, as over urban areas, anthropogenic emissions from shipping or pollution plumes from European big cities may influence biogenic SOA formation (Sartelet et al., 2012).

The VOC biogenic precursors of SOA are isoprene, monoterpenes (MT) and sesquiterpenes. Although sesquiterpenes emission factors are lower than those of isoprene and MT over Europe, their SOA yields are high because of their low saturation vapour pressures (Jaoui et al., 2013). For MT, first-generation oxidation products, such as pinonaldehyde, pinic and pinonic acids contribute to the formation of SOA, although their contributions may be low (Praplan et al., 2015). For $\alpha$-pinene, further-generation oxidation steps may lead to the formation of very low-volatility products, such as the tricarboxylic acid 3-methyl-1,2,3-butanetricarboxylic acid (MBTCA; Müller et al., 2012; Kristensen et al., 2014) and oligomeric compounds. Ehn et al. (2014) and Kristensen et al. (2014) showed that highly oxidised organic compounds are formed in the early stages of the oxidation of MT. Rissanen et al. (2015) proposed a mechanistic description of these extremely low-volatility organic compounds (ELVOCs) formation from the most atmospherically abundant biogenic monoterpenes, such as $\alpha$-pinene and limonene. These ELVOCs have been observed during both chamber and in situ measurements in Germany (Mutzel et al., 2015). Several studies showed the importance of nighttime SOA formation from MT via nitrate radical oxidation, resulting in the formation of organic nitrates (Pye et al., 2015; Bean and Ruiz, 2016; Xu et al., 2015; Nah et al., 2016). Pye et al. (2010) showed the importance of reactive nitrogen and pointed out the fact that organic nitrate accounts for more than a half of the monoterpene oxidation products in the particle phase over the US.

For isoprene, in low- $\mathrm{NO}_{x}$ environments, recent studies have focused on the formation of isoprene epoxydiols (IEPOX) in acidic aerosols (Surratt et al., 2010; Couvidat et al., 2013b). However, using AMS measurements, particlephase IEPOX was not observed during the ChArMEx campaign over an isoprene-emitting forest in the south of France, suggesting it might have formed organosulfates (Freney et al., 2017). Several studies also showed the importance of non-IEPOX pathway for isoprene oxidation in low- $\mathrm{NO}_{x}$ environment (Krechmer et al., 2015; Liu et al., 2016). Although ELVOCs may also form from isoprene oxidation, the yields may be low (Jokinen et al., 2015).

OA can also be emitted from the sea because of phytoplankton activity; according to O'Dowd et al. (2004), OA from marine origin can contribute considerably to OA concentrations, especially near the biologically productive waters. Recently derived parameterisations (Gantt et al., 2012; 
Schwier et al., 2015) relate the organic fraction of sea-salt emissions to the seawater chlorophyll $a$ ( $\mathrm{chl} a$ ) concentrations. However, the contribution of these species to the organic budget over the Mediterranean Sea is not clear.

SOA modelling has undergone significant progress over the past few years due to the rapid increase of experimental data on SOA yields and molecular chemical composition resulting from the oxidation of a variety of VOC and I/SVOC. SOA models used in mesoscale models can be grouped into two major categories: (1) models based on an empirical representation of SOA formation and (2) models based on a mechanistic representation of SOA formation. Models of the first category include the widely used two-compound Odum approach (Odum et al., 1996), the more recent volatility basis set (VBS) approach (Donahue et al., 2006, 2011) or the multi-generational oxidation model (Jathar et al., 2015). Models of the second category use experimental data on the molecular composition of SOA and represent the formation of SOA using surrogate molecules with representative physicochemical properties (Pun et al., 2006; Bessagnet et al., 2008; Carlton et al., 2010; Couvidat et al., 2012). The surrogate approach differentiates low- $\mathrm{NO}_{x}$ and high$\mathrm{NO}_{x}$ regimes. The gas-particle partitioning may include both absorption into hydrophobic organic particles and dissolution into aqueous particles and take into account some of the complexity involved in OA partitioning (such as nonideality, multi-phase partitioning). Although these two categories of models are fundamentally different in their initial design (empirical vs. mechanistic), they aim to describe the same processes. Furthermore, they tend to converge as they continue to be developed and refined. For example, I/S-VOCs from anthropogenic emissions, which are usually specified by volatility classes, can be included in a mechanistic model (Albriet et al., 2010; Couvidat et al., 2013a); also, the VBS scheme can take into account the oxidative state of SOA (Jimenez et al., 2009), in particular its elemental O/C ratio (Donahue et al., 2011; Jathar et al., 2015). The recently developed 1.5-VBS (Koo et al., 2014) assigned a molecular structure to VBS products. Both the mechanistic and empirical approaches are scientifically valid and complementary; as shown by Kim et al. (2011a), the most important aspect of an SOA model is its comprehensiveness in terms of the precursors and processes being treated (completeness of the precursor VOC list, importance of low- $\mathrm{NO}_{x}$ vs. high- $\mathrm{NO}_{x}$ regimes, treatment of hydrophilic properties of the surrogates) rather than its fundamental design. Cholakian et al. (2017) study how the VBS approach can be used to represent the formation of SOA over the western Mediterranean and point out the importance of taking into account fragmentation and formation of nonvolatile SOA in this framework.

This paper aims to investigate the chemical processes and surrogates that need to be taken into account in the mechanistic representation of SOA to reproduce the concentrations and properties of the observed biogenic SOA at the Ersa supersite in Corsica. The mechanistic representation in- cluded in the air-quality model Polyphemus (Couvidat et al., 2012) is modified by including recent research progress on monoterpenes SOA formation (ELVOC, MBTCA, organic nitrate). The influence of primary marine organic emissions is also studied. A further evaluation of the model by comparison to airborne measurements is presented in Freney et al. (2017).

The paper is structured as follows. Section 2 presents the air-quality model used and the improvements made in the mechanistic representation. Section 3 details the model input data sets and the measurement data. Section 4 compares the concentrations and the properties of OA to measurements, as well as the influence of the different chemical processes added to the model. Finally, Sect. 5 studies the impact of the biological activity of the Mediterranean Sea on OA concentrations.

\section{Model description}

\subsection{General features}

In order to simulate aerosol formation over the western Mediterranean, the Polair3d/Polyphemus air-quality model is used (Mallet and Sportisse, 2005). The numerical algorithms used for transport and the parameterisations used for dry and wet depositions are detailed in Sartelet et al. (2007). Gasphase chemistry is modelled with the carbon bond 05 mechanism (CB05) (Yarwood et al., 2005). Different reactions are added to CB05 to model the formation of semivolatile organic compounds from five classes of SOA precursors (intermediate and semivolatile organic compounds of anthropogenic emissions, aromatic compounds, isoprene, monoterpenes and sesquiterpenes) (Kim et al., 2011b; Couvidat et al., 2012). For these classes of precursors, which include a great number of species, only a few surrogates are used to represent all the species.

As detailed in Couvidat and Seigneur (2011), isoprene may form tetrols and methyl dihydroxy dihydroperoxide under low $\mathrm{NO}_{x}$, and methyl glyceric acids and organic nitrates under high $\mathrm{NO}_{x}$. Oxidation of isoprene by the nitrate radical $\mathrm{NO}_{3}$ is also modelled.

For monoterpenes and sesquiterpenes, the oxidation scheme is based on Pun et al. (2006). Humulene is used to represent all sesquiterpenes. For monoterpenes, three precursors are used: API (for $\alpha$-pinene and sabinene), BPI (for $\beta$-pinene and $\delta^{3}$-carene) and LIM (for limonene and other monoterpenes and terpenoids). Depending on the $\mathrm{NO}_{x}$ regimes, three surrogates are formed: pinonaldehyde, norpinic acid and pinic acid. Although a simple parameterisation was developed to represent the oligomerisation of pinonaldehyde as a function of $\mathrm{pH}$ in Couvidat et al. (2012), it is not used here because its influence on SOA formation is not clear. As detailed in Couvidat et al. (2012), I/S-VOC emissions are emitted as three primary surrogates of differ- 
Table 1. Precursors classes and the surrogate species used for SOA formation.

\begin{tabular}{ll}
\hline Precursors & Surrogate species \\
\hline I/S-VOCs & Three volatility bins: $\log \left(C^{*}\right)=-0.04,1.93,3.5$ with $C^{*}$ the saturation concentration \\
Aromatics & Toluene, xylene \\
Isoprene & Isoprene \\
Monoterpenes & $\alpha$-Pinene, $\beta$-pinene, limonene \\
Sesquiterpenes & Humulene \\
\hline
\end{tabular}

ent volatilities (characterized by their saturation concentrations $\left.C^{*}: \log \left(C^{*}\right)=-0.04,1.93,3.5\right)$. The ageing of each primary surrogate is represented through a single oxidation step, without $\mathrm{NO}_{x}$ dependance, to produce a secondary surrogate of lower volatility $\left(\log \left(C^{*}\right)=-2.4,-0.064,1.5\right.$ respectively) but higher molecular weight. For aromatic compounds, toluene and xylene are used as surrogate precursors. The precursors react with $\mathrm{OH}$ to form radicals that may then react differently under low- $\mathrm{NO}_{x}$ and high- $\mathrm{NO}_{x}$ conditions. Under low- $\mathrm{NO}_{x}$ conditions, the surrogate is not identified, but it is supposed to be hydrophobic. Under high- $\mathrm{NO}_{x}$ conditions, the surrogates formed are two benzoic acids (methyl nitrobenzoic acid and methyl hydroxy benzoic acid). Table 1 describes the five classes of precursors used to represent the SOA formation and the surrogates used.

The SIze REsolved Aerosol Model (SIREAM; Debry et al., 2007) is used for simulating the dynamics of the aerosol size distribution by coagulation and condensation/evaporation. SIREAM uses a sectional approach and the aerosol distribution is described here using 20 sections of bound diameters: 0.01, 0.0141, 0.0199, 0.0281, 0.0398, $0.0562,0.0794,0.1121,0.1585,0.2512,0.3981,0.6310,1.0$, $1.2589,1.5849,1.9953,2.5119,3.5481,5.0119,7.0795$ and $10.0 \mu \mathrm{m}$. The condensation/evaporation of inorganic aerosols is determined using the thermodynamic model ISORROPIA (Nenes et al., 1998) with a bulk equilibrium approach in order to compute partitioning between the gaseous and condensed phases of particles.

For organic aerosols, the gas-particle partitioning of the surrogates is computed using SOAP (Couvidat and Sartelet, 2015), and bulk equilibrium is also assumed for SOA partitioning. The gas-particle partitioning of hydrophobic surrogates is modelled following Pankow (1994), with absorption by the organic phase (hydrophobic surrogates). The gasparticle partitioning of hydrophilic surrogates is computed using the Henry's law modified to extrapolate infinite dilution conditions to all conditions using an aqueous-phase partitioning coefficient, with absorption by the aqueous phase (hydrophilic organics, inorganics and water). Activity coefficients are computed with the thermodynamic model UNIFAC (UNIversal Functional group; Fredenslund et al., 1975). After condensation/evaporation, the moving diameter algorithm is used for mass redistribution among size bins.
Table 2. ELVOC yields and uncertainties.

\begin{tabular}{lll}
\hline VOC & Ehn et al. (2014) & Jokinen et al. (2015) \\
\hline$\alpha$-Pinene & $7 \% \pm 3.5 \%$ & $3.4 \% \pm 1.7 \%$ \\
Limonene & $17 \% \pm 8.5 \%$ & $5.3 \% \pm 2.6 \%$ \\
\hline
\end{tabular}

\subsection{ELVOCs}

Ehn et al. (2014) and Kristensen et al. (2014) showed that extremely low-volatility hydrophobic molecules of high molecular weight form at the early stage of oxidation of the monoterpenes $\alpha$-pinene and limonene by ozone. In the model, a unique gaseous precursor representing $\alpha$-pinene and limonene is used for ELVOC formation. The ELVOC yield is assumed to be $11 \%$, i.e. close to the average of the yields of $\alpha$-pinene and limonene according to Ehn et al. (2014). Jokinen et al. (2015) suggested lower yields (Table 2). In this paper, sensitivity simulations with a lower bound of $3 \%$ and a upper bound of $18 \%$ are also conducted.

Relying on known chemistry and experimental findings, Ehn et al. (2014) and Rissanen et al. (2015) provided a formation pathway from monoterpenes to ELVOCs through the autoxidation process (Crounse et al., 2013).

The ozonolysis reaction leads to the formation of peroxy radicals $\left(\mathrm{RO}_{2}\right)$, which are the starting point of ELVOC formation. These radicals undergo a fairly rapid $\left(\sim 1 \mathrm{~s}^{-1}\right)$ sequential intramolecular $\mathrm{H}$-atom shift followed by $\mathrm{O}_{2}$ addition leading to the formation of highly oxygenated peroxy radicals $\left(R_{\text {ELVOC }} \mathrm{O}_{2}\right)$. This $\mathrm{O}_{2}$ addition leads not only to an increase in molecular weight but also to a decrease in the radical volatilities. Rissanen et al. (2015) investigated these reactions including the different steps, possible isomerisation as well as the most likely chemical pathways leading to an enrichment of peroxy radicals by oxygen. The oxygen-centred peroxy radical intermediates are internally rearranged by intramolecular hydrogen shift reactions, enabling more oxygen molecules to attach to the carbon backbone. Simultaneously, the sequential $\mathrm{H}$-shift mechanism competes with reactions between peroxy radicals, $\mathrm{NO}$ and $\mathrm{HO}_{2}$. Subsequently, the termination reactions lead to the formation of ELVOCs. ELVOC monomers and dimers are formed through reactions of $R_{\mathrm{ELVOC}} \mathrm{O}_{2}$ with $\mathrm{RO}_{2}$ and $\mathrm{HO}_{2}$. Following Ehn et al. (2014), the reactions for the ozonolysis of $\alpha$-pinene 
and limonene (MT), as well as the kinetic constants used in the model (Table A1), are included in the model as detailed in Appendix A. The formation of organic nitrate from $R_{\text {ELVOC }} \mathrm{O}_{2}$ peroxy radicals is not considered in the model, as the reactions proposed by Ehn et al. (2014) led to negligible concentrations.

The aerosol species introduced in the model for ELVOC formation and their properties are detailed in Table 3. The enthalpy of vaporisation of the monomer and dimer is set to $50 \mathrm{KJ} \mathrm{mol}^{-1}$ (Svendby et al., 2008), and the saturation vapour pressure is assumed to be very low and is taken equal to $10^{-14}$ torr at $298 \mathrm{~K}$.

\subsection{Organic nitrates formation mechanism}

Organic nitrates are formed where biogenic VOCs and anthropogenic $\mathrm{NO}_{x}$ sources interact (Pye et al., 2015; Xu et al., 2015; Bean and Ruiz, 2016; Nah et al., 2016). We used here the parameterisation of Pye et al. (2015) to account for the formation of organic nitrate compounds from the oxidation by $\mathrm{OH}$ and $\mathrm{NO}_{3}$ of MT. The oxidation of MT by $\mathrm{OH}$ leads to the formation of a peroxy radical TERPRO ${ }_{2}$, and the oxidation by $\mathrm{NO}_{3}$ leads to the formation of TERPNRO (nighttime $^{2}$ chemistry). The peroxy radicals $\mathrm{TERPRO}_{2}$ may react with NO to form organic nitrate with a molar yield of $20.1 \%$, while the oxidation of TERPNRO ${ }_{2}$ leads to higher yields. The reactions, as well as the kinetic constants (Table B1) are described in Appendix B.

Following Pye et al. (2015), the estimated vapour pressure of the condensing organic nitrate species is assumed to be $5 \times 10^{-6}$ torr (Fry et al., 2009), and the enthalpy of vaporisation is taken as $40 \mathrm{KJ} \mathrm{mol}^{-1}$. The aerosol species (orgNIT) introduced in the model and its properties are summarised in Table 3. The organic nitrate is assumed to be hydrophobic (Liu et al., 2012).

\subsection{MBTCA: an aging product of the pinonic acid}

It was shown in a set of studies that ozonolysis and $\mathrm{OH}$-initiated reactions of terpenes produce organic acids (Hatakeyama et al., 1991; Hoffmann et al., 1997; Warnke et al., 2006). Szmigielski et al. (2007) identified MBTCA (3-methyl-1,2,3-butanetricarboxylic acid) as the most relevant organic acid for atmospheric SOA. It is produced by the $\mathrm{OH}$ oxidation of pinonic acid, which is itself produced by the $\mathrm{OH}$ oxidation of $\alpha$-pinene. The $\mathrm{OH}$ oxidation of pinonic acid to form MBTCA is added to the model with a kinetic constant $k=9.0 \times 10^{-12} \mathrm{~cm}^{3} \mathrm{~s}^{-1}$ (Jaoui and Kamens, 2001) and a yield of 0.0061 (Müller et al., 2012). Following Couvidat et al. (2012), MBTCA is supposed to be hydrophilic, with a $\mathrm{OM} / \mathrm{OC}$ ratio of 2.125 (Table 3).

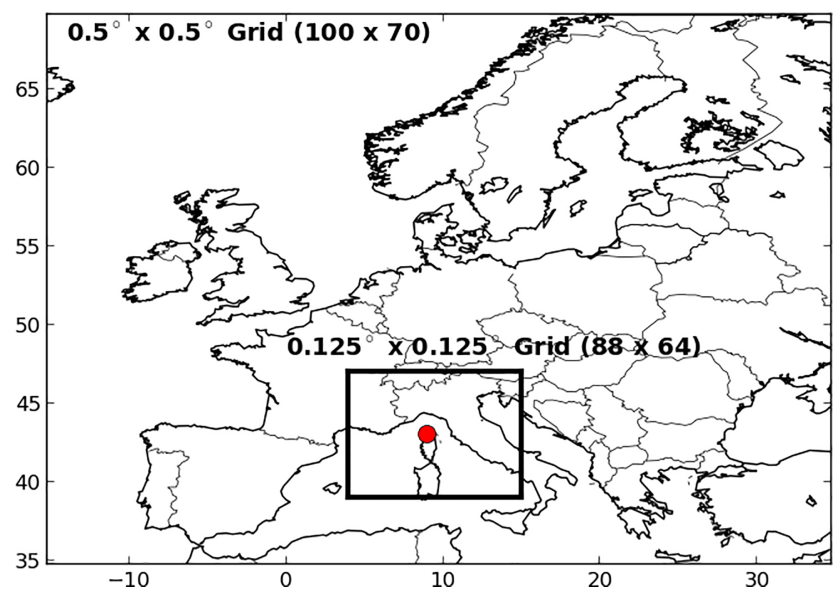

Figure 1. The nested modelling domains: the nesting domain over Europe and a nested domain over the northwestern Mediterranean, as delimited by a black rectangular contour in the figure. The red point indicates the Ersa station in Corsica Island.

\section{Model and measurement setup}

The simulation domain and the input data are now detailed, as well as the measurements used in this study.

\subsection{Model setup}

\subsubsection{Domains}

Two nested simulations are performed: one over Europe and one over a Mediterranean domain centred around the Ersa supersite surroundings in Corsica (Fig. 1).

The coordinates of the European southwestern-most point are $15^{\circ} \mathrm{W}, 35^{\circ} \mathrm{N}$ in longitude and latitude. The domain of simulation covers an area of $50^{\circ} \times 35^{\circ}$ with a uniform spatial step of $0.5^{\circ}$ along both longitude and latitude. For the nested Mediterranean domain, the southwestern-most point is $4^{\circ} \mathrm{W}$, $39^{\circ} \mathrm{N}$. The domain of simulation covers an area of $11^{\circ} \times 8^{\circ}$ with a uniform spatial step of $0.125^{\circ}(\sim 13 \mathrm{~km})$ along both longitude and latitude. Fourteen vertical levels are considered from the ground to $12 \mathrm{~km}$. The heights of the cell interfaces are $0,30,60,100,150,200,300,500,750,1000,1500,2400$, 3500,6000 and $12000 \mathrm{~m}$.

The dates of simulation are chosen such as matching those of the measurements. For 2012, the simulations are run between 2 June and 8 July 2012 for the nesting domains ( 6 June and 8 July 2012 for nested). For 2013, the simulations are run between 2 June and 10 August 2013) for the nesting domains (6 June and 10 August 2013 for nested).

Boundary conditions for the European domain are obtained from the global chemistry-transport model MOZART v4 (Horowitz et al., 2003) (https://www.acom.ucar.edu/ wrf-chem/mozart.shtml). The European simulation provides initial and boundary conditions to the Mediterranean simulation. 
Table 3. Species introduced in the extremely low-volatility organic compounds (ELVOC), organic nitrate (orgNIT) and MBTCA kinetic models.

\begin{tabular}{llrrrrr}
\hline Species & $\begin{array}{l}\text { Molecular } \\
\text { formula }\end{array}$ & $\begin{array}{r}\text { Molar } \\
\text { weight } \\
\left(\mathrm{g} \mathrm{mol}^{-1}\right)\end{array}$ & $\begin{array}{r}\text { Saturation vapour } \\
\text { pressure at 298 K } \\
\text { (torr) }\end{array}$ & $\begin{array}{r}\text { Enthalpy of } \\
\text { vaporisation } \\
\left(\mathrm{KJ} \mathrm{mol}^{-1}\right)\end{array}$ & $\mathrm{OM} / \mathrm{OC}$ & $\mathrm{O} / \mathrm{C}$ \\
\hline Monomer ELVOC & $\mathrm{C}_{10} \mathrm{H}_{14} \mathrm{O}_{9}$ & 278 & $1.0 \times 10^{-14}$ & 50.0 & 2.3 & 1.2 \\
Dimer ELVOC & $\mathrm{C}_{19} \mathrm{H}_{28} \mathrm{O}_{11}$ & 432 & $1.0 \times 10^{-14}$ & 50.0 & 1.9 & 0.8 \\
OrgNIT & $\mathrm{C}_{10} \mathrm{H}_{17} \mathrm{NO}_{5}$ & 231 & $5.0 \times 10^{-6}$ & 40.0 & 1.9 & 0.7 \\
MBTCA & $\mathrm{C}_{8} \mathrm{H}_{12} \mathrm{O}_{6}$ & 204 & $3.25 \times 10^{-7}$ & 109 & 2.1 & 1.0 \\
SSorg & & 136 & $6.60 \times 10^{-8}$ & 50.0 & & \\
\hline
\end{tabular}

\subsubsection{Meteorological data}

Meteorological data are provided by the European Centre for Medium-Range Weather Forecasts (ECMWF) model. The vertical diffusion is computed using the Troen and Mahrt parameterisation (Troen and Mahrt, 1986). The Global Land Cover 2000 (GLC-2000; http://forobs.jrc.ec.europa.eu/ products/glc2000/data_access.php) data set is used for land cover.

\subsubsection{Emissions}

Anthropogenic emissions are generated using the EDGARHTAP_V2 inventory for 2010 (http://edgar.jrc.ec.europa.eu/ htap_v2/). The monthly and daily temporal distribution for the different activity sectors are obtained from GENEMIS (1994) and the hourly temporal distribution from Sartelet et al. (2012). Following Sartelet et al. (2007), $\mathrm{NO}_{x}$ emissions are split in mass into $90 \%$ of $\mathrm{NO}, 9.2 \%$ of $\mathrm{NO}_{2}$ and $0.8 \%$ of HONO. $\mathrm{SO}_{x}$ emissions are split into $98 \%$ of $\mathrm{SO}_{2}$ and $2 \%$ of $\mathrm{H}_{2} \mathrm{SO}_{4}$ (in molar concentrations). For emissions of non-methane volatile organic compounds, the speciation of Passant (2002) is used. $\mathrm{PM}_{2.5}$ primary particle emissions are speciated into dust, POA and black carbon. POA are assumed to be the particle phase of I/S-VOC. Total I/S-VOC emissions (gas and particle phases) are estimated as detailed in Couvidat et al. (2012) by multiplying POA by a fixed value and by assigning them to species of different volatilities. The volatility distribution is kept the same for all emission sectors, although more detailed volatility distributions could be defined following the work of May et al. (2013a, b); Jathar et al. (2014). In this study, the ratio I/S-VOC/POA is set to 2.5 (Kim et al., 2016) and (Zhu et al., 2016). Setting the ratio of semivolatile organic carbon to POA to 1, i.e. ignoring I/S-VOC, has little impact on the organic concentrations, as shown in Fig. 2. Particles of diameters higher than $2.5 \mu \mathrm{m}$ are all speciated into dust. Biogenic emissions are estimated with the Model of Emissions of Gases and Aerosols from Nature (MEGAN; Guenther et al., 2006). Over the Mediterranean domain, during the period of the 2013 summer simulation, the average emissions of sesquiterpenes, monoterpenes and isoprene are $0.001,0.019$ and $0.024 \mu \mathrm{g} \mathrm{m}^{-2} \mathrm{~s}^{-1}$ respectively.

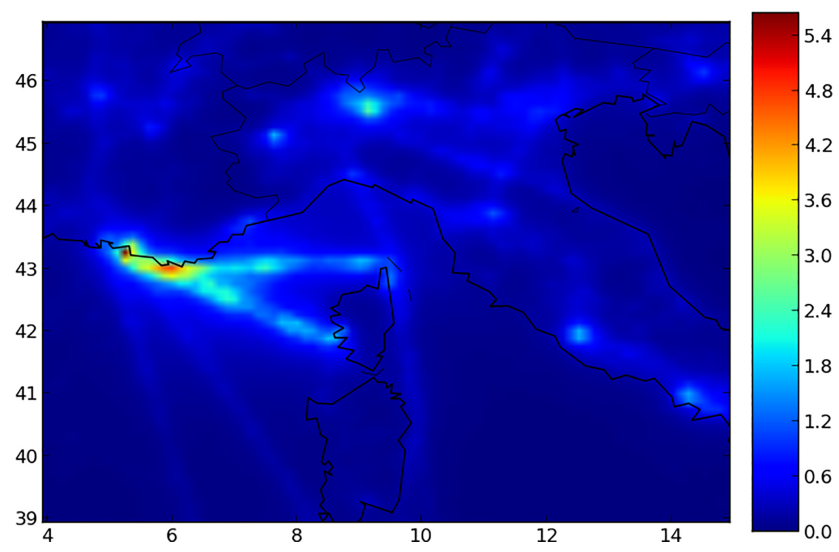

Figure 2. Relative difference $(\%)$ of $\mathrm{OM}_{1}$ concentrations simulated using the emission ratio $\mathrm{I} / \mathrm{S}-\mathrm{VOC} / \mathrm{POA}=2.5$ and 1 .

Hence, compared to isoprene and monoterpene emissions, the sesquiterpene emissions are lower by a factor of 95.8 and $94.7 \%$ respectively.

Sea-salt emissions are parameterised following Jaeglé et al. (2011), who modelled the generation of sea salt by the evaporation of sea spray produced by bursting bubbles during whitecap formations due to the friction with surface wind. The emitted sea-salt mass is assumed to be made of $30.61 \%$ sodium (Seinfeld and Pandis, 2006), $25.40 \%$ chloride and $4.22 \%$ sulfate following results from measurements in mesocosms made in Corsica in July 2012 (Schwier et al., 2015). The organic fraction of sea-salt emissions is not taken into account in the simulation presented here. However, it is estimated in Sect. 5, where the contribution of organic seasalt emissions to organic concentrations is assessed.

\subsection{Measured data}

The model results are compared to observational data from ChArMEx campaigns during the summers of 2012 and 2013. The station is located at the red point in Fig. 1. The measurement site is located at Ersa $\left(42^{\circ} 58^{\prime} \mathrm{N}, 9^{\circ} 21.8^{\prime} \mathrm{E}\right)$, on a ridge at an altitude of about $530 \mathrm{~m}$ above the sea level, and has an unimpeded view of the sea over $\sim 300^{\circ}$ from the SSW to 
SSE (Mallet et al., 2016). The ground-based comparisons are performed by comparing the measured concentrations to the simulated ones using the concentrations of the model cell the closest to the station. The central coordinates of this cell at which concentrations are computed are $42^{\circ} 52 \mathrm{~N}, 9^{\circ} 22^{\prime} 30^{\prime \prime} \mathrm{E}$, which is very close to the station and with a similar altitude above sea level (494 m). Cholakian et al. (2017) studied the difficulty to correctly represent in a model the orography of Ersa site, which is a cape at the northern edge of Corsica. They concluded that the representativeness error is about $10 \%$ for organic aerosols.

To evaluate the organic concentrations and oxidation properties, an ACSM (aerosol chemical speciation monitor) was used to measure the real-time chemical composition and mass loading of aerosols with aerodynamic diameters between 70 and $1000 \mathrm{~nm}$ (sulfate, nitrate, ammonium, chloride and organic compounds), between 8 June and 2 July 2012 and between 6 June and 3 August 2013. The ratio OM/OC and the oxidation state of organics are estimated using the ACSM measurements following Kroll et al. (2011).

Other instruments were deployed in 2013 to evaluate the organic properties: a PILS-TOC-UV to estimate the watersoluble fraction of organics (Sciare et al., 2011) between 14 July and 5 August 2013 and a high-volume quartz filter sampling DIGITEL for ${ }^{14} \mathrm{C}$ measurements in organics between 16 and 30 July 2013.

A direct evaluation of the simulated concentrations of ELVOCs or organic nitrates cannot be done because they were not measured during the campaigns.

\subsection{Model-measurements comparison method}

To evaluate a model, several approaches and performance scores can be used. Here, we compare model simulation results to measurements using a set of performance statistical indicators: the simulated mean $(\bar{s})$, the root mean square error (RMSE), the correlation coefficient, the mean fractional bias (MFB) and the mean fractional error (MFE). They are defined in Table C1 of Appendix C. Based on the MFB and the MFE, Boylan and Russell (2006) proposed a performance and a goal evaluation criteria as detailed in Table C2 of Appendix $\mathrm{C}$.

\section{Comparison to measurements}

The concentrations of organic aerosols are compared to measurements for the summers of 2012 and 2013. The origins of organic aerosols (fossil vs. non-fossil), and their properties (oxidation state, hydrophilic properties) are compared to the measurements performed during the intensive measurement period of the summer 2013. In the simulation presented here, the ELVOC yield is assumed to be $11 \%$, as detailed in Sect. 2.2. Two sensitivity simulations are performed using a lower bound yield (3\%) and an upper bound yield (18\%).
In Appendix D, similarly to what is presented in this section for the reference simulation, the sensitivity simulations are compared to each other and to the measurements in terms of the mass of $\mathrm{OM}_{1}$, the organic aerosol composition and the $\mathrm{OM} / \mathrm{OC}$ and $\mathrm{O} / \mathrm{C}$ ratios.

\subsection{Organic concentrations}

The comparisons of the measured and modelled temporal profiles of the concentration of the submicron organic mass $\left(\mathrm{OM}_{1}\right)$ at Ersa are shown in Fig. 3 for the two summer campaigns of 2012 and 2013.

The model shows satisfactory results at Ersa station, as shown by the statistics in Table 4 . Both the goal and the performance criteria of Boylan and Russell (2006) are verified for both years (MFB $<30 \%$ and $\mathrm{MFE}<50 \%$ ). The overall concentration of $\mathrm{OM}_{1}$ is reasonably well modelled, although it is slightly underestimated 2.58 (3.71) $\mu \mathrm{g} \mathrm{m}^{-3}$ against 2.89

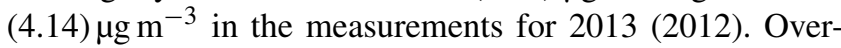
all, the model reproduces very well the peaks and troughs of $\mathrm{OM}_{1}$ concentrations in both 2012 and 2013 with the exception of a few days in late June-early July 2013. This period is a period with air trajectories passing over France (Arndt et al., 2017), during which aging processes of biogenic compounds may be particularly important with formation of aged hydrophilic SOA. In the model, this process would lead to the formation of aged carboxylic acids, with MBTCA used as surrogate. However, the simulated concentration is low because the yield used is very low (it corresponds to the yield of MBTCA only).

\subsection{Sources of OA}

In both 2012 (6 June to 8 July) and 2013 (6 June to 10 August), the modelled organic mass is dominated essentially by biogenic particles (Fig. 4). They represent 77 and $75 \%$ of the organic mass. In the model, for comparisons to the ${ }^{14} \mathrm{C}$ measurements, the biogenic-origin organic compounds are assumed to be non-fossil, and the anthropogenicorigin organic compounds are assumed to be fossil. Although in winter, some of the anthropogenic-origin organic compounds may originate from wood combustion (residential heating) and be non-fossil, we assume that the fraction of anthropogenic-origin organic compounds from residential heating is low in summer. The simulated OC is computed by dividing the modelled organic mass of each model surrogate by the OM / OC ratio of the surrogate.

During the period when ${ }^{14} \mathrm{C}$ measurements were performed (16 to $30 \mathrm{July}$ ), $75 \%$ of the modelled organic mass is biogenic, in agreement with the ${ }^{14} \mathrm{C}$ measurements, which estimated that $85 \%$ is non-fossil. The measured and simulated means are 2.5 and $1.9 \mathrm{\mu g} \mathrm{m}^{-3}$, respectively, for nonfossil $\mathrm{OC}$, and 0.5 and $0.6 \mu \mathrm{gC} \mathrm{m}^{-3}$, respectively, for fossil OC. Although fossil OC is well modelled, non-fossil OC is slightly underestimated between 16 and 30 July. 

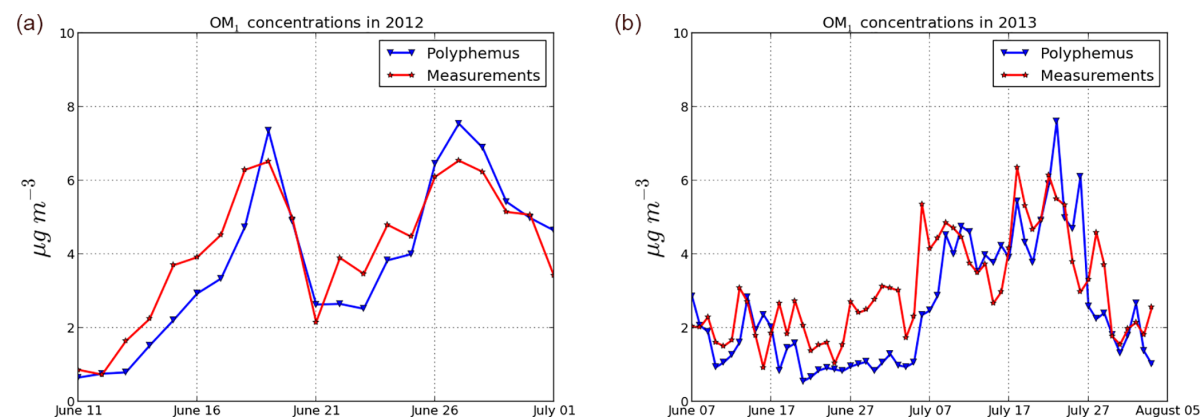

Figure 3. Comparison of measured and simulated daily $\mathrm{OM}_{1}$ concentration at Ersa during the summer campaigns of 2012 (a) and 2013 (b).

Table 4. Statistics of model to measurements comparisons for hourly organic concentrations in particles of diameters lower than $1 \mu \mathrm{m}$ during the summer campaigns of 2012 and 2013. $\bar{o}$ and $\bar{s}$ are the observed and simulated means respectively. RMSE is the root mean square error, and MFB and MFE are the mean fractional bias and error respectively (see Appendix C).

\begin{tabular}{rrrrrrr}
\hline Year & $\bar{o}\left(\mu \mathrm{g} \mathrm{m}^{-3}\right)$ & $\bar{s}\left(\mu \mathrm{g} \mathrm{m}^{-3}\right)$ & $\operatorname{RMSE}\left(\mu \mathrm{g} \mathrm{m}^{-3}\right)$ & Correlation $(\%)$ & MFB & MFE \\
\hline 2012 & 4.14 & 3.71 & 2.00 & 61.7 & -0.13 & 0.39 \\
2013 & 2.89 & 2.58 & 1.53 & 67.3 & -0.15 & 0.49 \\
\hline
\end{tabular}

The modelled average chemical compositions of $\mathrm{OM}_{1}$ at Ersa during the summers of 2012 and 2013 are presented in Fig. 4. The chemical composition is very similar between the years 2012 and 2013.

Monoterpene oxidation products including ELVOCs and organic nitrate represent a large part of biogenic aerosols (about $48 \%$ in 2012 and 2013). ELVOCs and organic nitrate are abundant. ELVOCs represent $10 \%$ of $\mathrm{OM}_{1}$ in 2012 and $15 \%$ in 2013. Organic nitrate represent $24 \%$ of the organic mass in 2012 and $20 \%$ in 2013. The route to organic particulate nitrate may essentially (but not exclusively) be active during the night as $\mathrm{NO}_{3}$ efficiently photolyses during the day and the production yields are more important during the night, and higher organic-nitrate concentrations are observed at night (Fig. 5).

MBTCA, an oxidation product of MT, represents a tiny portion of $\mathrm{OM}_{1}$, following the very low molar yield used. After MT, the most important biogenic precursor is isoprene; its oxidation products represent about $20 \%$ of $\mathrm{OM}_{1}$ in 2012 and $16 \%$ in 2013. Although sesquiterpenes emissions are lower than isoprene and monoterpenes emissions, their oxidation products represent about $10 \%$ of $\mathrm{OM}_{1}$. Anthropogenic oxidation products represent about 22 and $25 \%$ of $\mathrm{OM}_{1}$ in 2012 and 2013 respectively. Most of anthropogenic oxidation products originate from intermediate and semivolatile organic emissions (about $19 \%$ of $\mathrm{OM}_{1}$; they are referred to as anthropogenic SOA and POA in Fig. 4) and from aromatic oxidation products ( 3 to $5 \%$ of $\mathrm{OM}_{1}$ ).

\subsection{Oxidation state of organics}

The level of oxidation of ambient organic aerosols is assessed by the ratio of organic matter to organic carbon
$(\mathrm{OM} / \mathrm{OC})$ and the ratio of oxygen to carbon ratio $(\mathrm{O} / \mathrm{C})$. $\mathrm{OM}$ is made up of many different molecular structures and it may include not only particulate organic carbon but also oxygen, hydrogen, nitrogen and/or sulfate. Hence, a high $\mathrm{OM} / \mathrm{OC}$ ratio indicates a high degree of oxidation of the organic aerosols and probably a high degree of hygroscopicity (Jimenez et al., 2009). There is a variety of methods that have been used to calculate $\mathrm{OM} / \mathrm{OC}$ ratio as reported by Xing et al. (2013). In our case, the ambient OM / OC ratio is calculated by weighting the ratio $(\mathrm{OM} / \mathrm{OC})_{i}$ of each surrogate species $i$ by the relative mass of the surrogate: $\mathrm{OM} / \mathrm{OC}=\sum_{i=1}^{N_{\text {esp }}}(\mathrm{OM} / \mathrm{OC})_{i} \times \mathrm{OM}_{i} / \mathrm{OM}$, where $N_{\text {esp }}$ is the number of surrogate species. The ratio $(\mathrm{OM} / \mathrm{OC})_{i}$ of the surrogate species $i$ depends only on the molecular structure of the species and the number of carbons in the molecule. The $\mathrm{O} / \mathrm{C}$ ratio allows for the degree of oxygenation of the organics to also be considered.

The measured and simulated temporal evolutions of both $\mathrm{OM} / \mathrm{OC}$ and $\mathrm{O} / \mathrm{C}$ ratios for submicron organic aerosols are shown in Fig. 6 during the whole summer 2013 campaign period. The contributions from ELVOCs, organic nitrate and MBTCA are highlighted.

Relying on the measured values, the organic species over Ersa are highly oxidised and oxygenated. In fact, the measured value of the $\mathrm{OM} / \mathrm{OC}$ ratio (2.43) is higher than the value of 2.1 suggested by Turpin and Lim (2001) for a rural site like Kern Refuge (US). The measured O / C ratio is 0.99. In agreement with the measurements, all simulations show a relatively stable $\mathrm{OM} / \mathrm{OC}$ ratio and $\mathrm{O} / \mathrm{C}$ ratio during the simulated period.

Without taking into account the ELVOCs, MBTCA and organic nitrate species, the model strongly underestimates both 

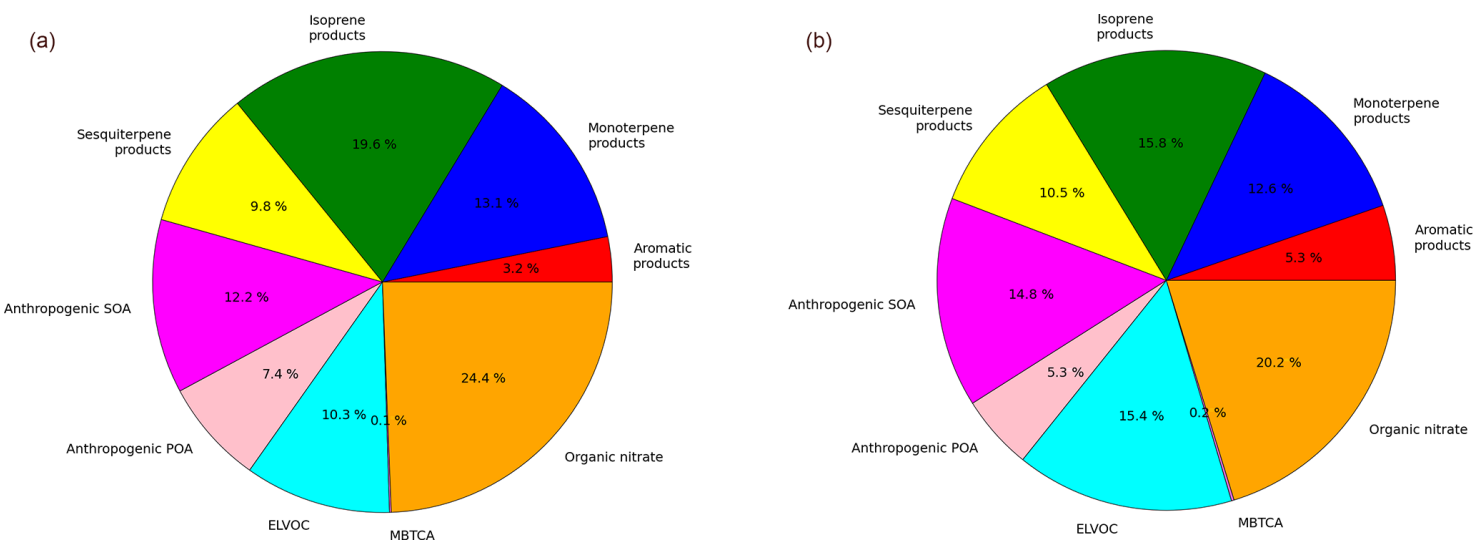

Figure 4. Simulated composition of $\mathrm{OM}_{1}$ during the summer campaigns of 2012 (a) and 2013 (b).

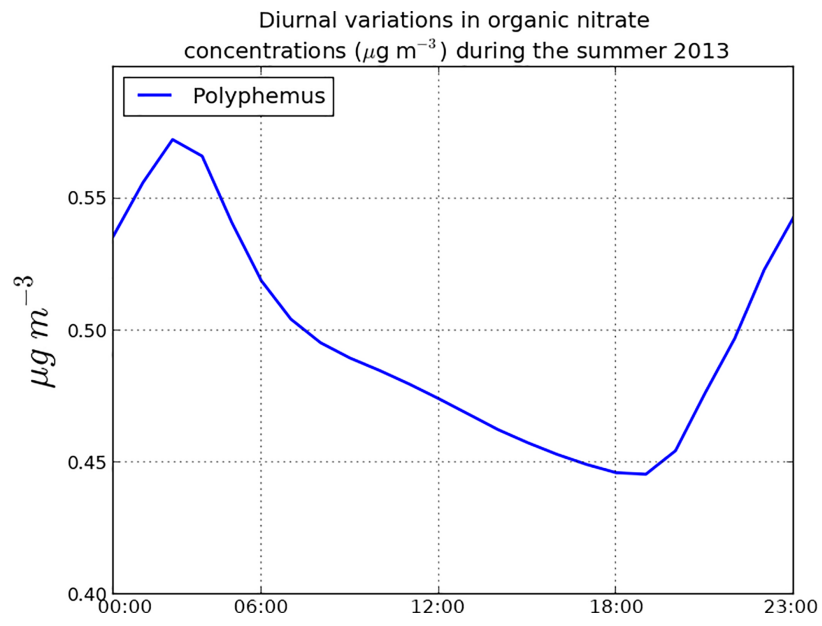

Figure 5. Diurnal variations in simulated organic nitrate concentrations during summer 2013 at ERSA.

the $\mathrm{OM} / \mathrm{OC}$ ratio and the $\mathrm{O} / \mathrm{C}$ ratio. This is because of the absence of highly oxidised species in the model, as all the other modelled organic compounds with non-negligible mass tend to have low $\mathrm{OM} / \mathrm{OC}$ and $\mathrm{O} / \mathrm{C}$ ratios.

Taking into account the formation of ELVOCs leads to improvements in the predicted oxidation state of aerosols: the $\mathrm{OM} / \mathrm{OC}$ ratio $(\mathrm{O} / \mathrm{C})$ changes from 1.57 to 1.89 (0.51 to $0.65)$, although the monomer and dimer ELVOCs only represent $15.7 \%$ of the $\mathrm{OM}_{1}$ mass.

MBTCA has a low impact on the organics oxidation level, despite its high OM / OC ratio, because it constitutes only a tiny part of the $\mathrm{OM}_{1}$ mass $(0.2 \%)$.

Taking into account organic nitrate leads to an improvement of both ratios. The OM / OC increases from 1.89 to 2.18 and the $\mathrm{O} / \mathrm{C}$ ratio increases from 0.65 to 0.73 .

A possible way to explain the underestimation of the $\mathrm{OM} / \mathrm{OC}$ ratio (2.17 simulated against 2.43 measured) and the $\mathrm{O} / \mathrm{C}$ ratio ( 0.73 simulated and 0.99 measured) is to take into account the formation of organosulfate. As both organic and sulfate are the major components of aerosols at Ersa (Nicolas, 2013), there may be formation of organosulfate, as suggested by the transmission electron microscopy measurements of Freney et al. (2017) in the south of France.

The measurements performed at Ersa show a good correlation between sulfate and organic $\mathrm{OM}_{1}$ concentrations, with a linear regression coefficient of 0.64 . In agreement with the measurements, the simulated concentrations of sulfate and organics are also well correlated with a linear regression coefficient of 0.71. Although the formation of organosulfate is not modelled here, the modelled correlation is high because both sulfate and organics are formed by oxidation of precursors, and oxidant concentrations largely depend on meteorological variables, such as temperature and dilution within a variable mixing layer. Furthermore, a large part of biogenic SOA is hydrophilic and therefore higher condensation of sulfate enhances their partitioning into the particulate phase, as the mass of the aqueous phase increases through the condensation of sulfate (Couvidat and Sartelet, 2015).

In laboratory, the formation of organosulfate was observed from the uptake of monoterpene oxidation products (pinonaldehyde) on acidic sulfate aerosols (Liggio and Li, 2006; Surratt et al., 2008), from the uptake of ELVOC (Mutzel et al., 2015) and from the uptake of isoprene oxidation products (Liggio et al., 2005; Nguyen et al., 2014). Isoprene SOA may be formed via the reactive uptake of IEPOX, a secondgeneration oxidation product of isoprene, in the presence of hydrated sulfate (Surratt et al., 2010; Couvidat et al., 2013b; Nguyen et al., 2014). Using AMS measurements, Hu et al. (2015) estimated that IEPOX-OA makes a large fraction of the OA (between 17 to $36 \%$ in the US) outside urban areas, in agreement with Budisulistiorini et al. (2015). In regions where aerosols are acidic, IEPOX-derived OA may be strongly dependent on the sulfate concentration, which acts as nucleophile and facilitates the ring-opening reaction of IEPOX and organosulfate formation (Nguyen et al., 2014; $\mathrm{Xu}$ et al., 2015). 

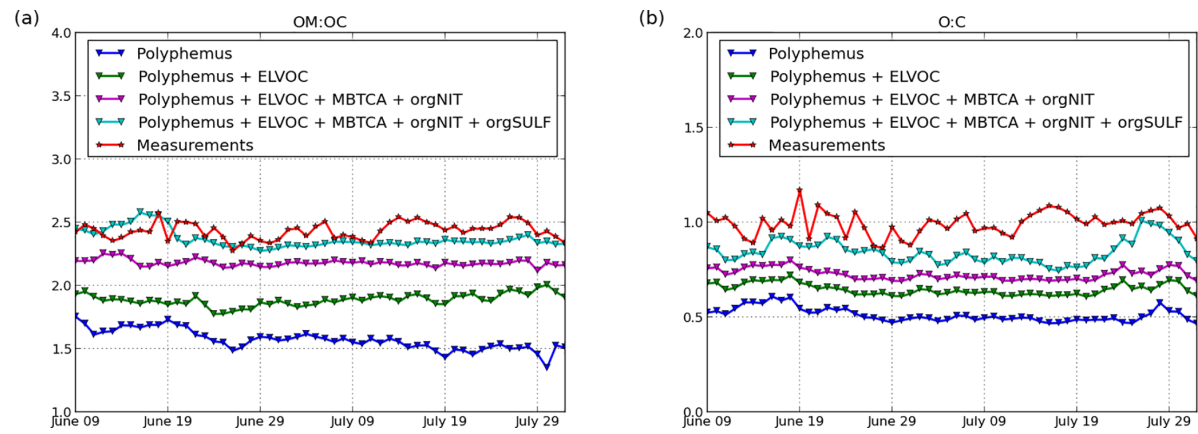

Figure 6. Daily variations of the ratios OM / OC (a) and O / C (b) during the 2013 campaign. The red line represents the measurements. The blue line represents model results without taking into account the concentrations of ELVOCs, MBTCA and organic nitrate. The green and magenta lines represent the model results by also taking into account ELVOCs (green) and MBTCA and organic nitrate (magenta). The cyan line represents the model results when assuming that a surrogate from isoprene oxidation is an organosulfate.

In order to take into account the influence of the formation of organosulfates on OA properties, the surrogate products of the model are modified. As Mediterranean aerosol composition displays large concentrations of sulfate, isoprene oxidation products may lead to the formation of organosulfate. In the model, the components formed from the low- $\mathrm{NO}_{x}$ oxidation of isoprene are BiPER and BiDER. The surrogate BiPER is supposed to be a methyl dihydroxy dihydroperoxide. Although BiDER is not identified, it is assumed to have the properties of a methyl tetrol (Couvidat and Seigneur, 2011). If we assumed that this compound has the same properties as a sulfate ester of formula $\mathrm{C}_{6} \mathrm{H}_{11} \mathrm{O}_{3} \mathrm{SO}_{4}$, the ratios $\mathrm{OM} / \mathrm{OC}$ and $\mathrm{O} / \mathrm{C}$ increase to get closer to measurements (Fig. 6). In fact, the average $\mathrm{OM} / \mathrm{OC}$ ratio $(\mathrm{O} / \mathrm{C})$ increases from 2.18 (0.73) to 2.37 (0.84), which compares very well with the average measured ratios (2.43 for OM / OC and 0.99 for $\mathrm{O} / \mathrm{C}$ ). Even though the ratio $\mathrm{O} / \mathrm{C}$ still seems to be slightly underestimated, the discrepancies may be explained by uncertainties in the measurements. Measurements performed at the same place between 10 July and 6 August with a high-resolution time-of-flight AMS shown an average OM / OC ratio of 2.34 $( \pm 0.14)$ and an average $\mathrm{O} / \mathrm{C}$ ratio $0.92( \pm 0.11)$.

\subsection{Water-soluble organics}

Water-soluble organics constitute a major fraction of organic compounds. On average between 15 and 31 July 2013, submicron water-soluble organic carbon (WSOC) represents $64 \%$ of the organic carbon in the measurements and $46 \%$ in the model. WSOC concentrations are well modelled on average (the measured mean is $1.0 \mu \mathrm{gC} \mathrm{m}^{-3}$ and the modelled mean is $0.9 \mu g \mathrm{C} \mathrm{m}^{-3}$ ). Figure 7 shows the daily concentrations of WSOC in the model and according to the measurements. Although the WSOC concentrations are well modelled between 21 and 31 July, they are underestimated between 15 and 20 July. These differences between the periods in the ability of the model to represent WSOC concentrations may be linked to differences in the organic aerosol composi-

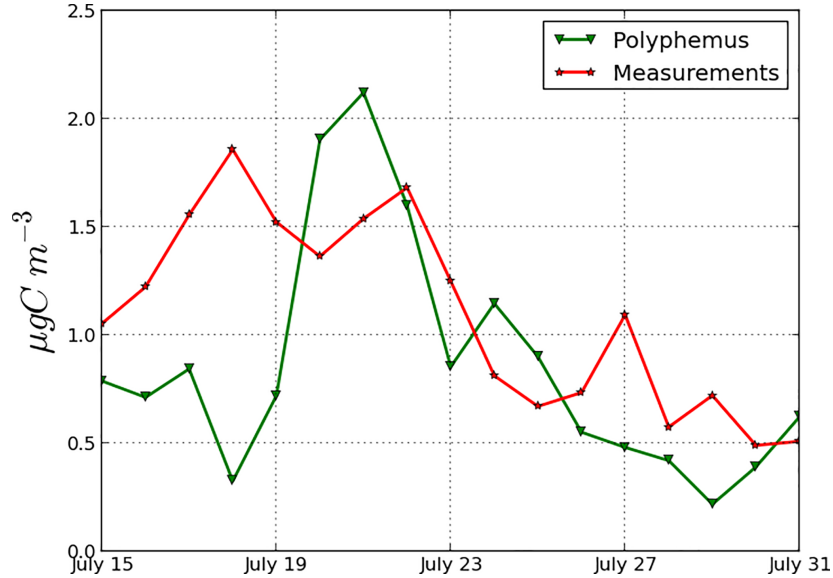

Figure 7. Measured and simulated submicron water soluble organic carbon $\left(\mu \mathrm{gC} \mathrm{m}^{-3}\right)$ at Ersa.

tion and in the origins of air masses. This is illustrated by the comparison of 16 and 30 July. WSOC concentrations are underestimated on 16 July but are well modelled on 30 July. 16 July is characterised by low/calm winds in a time when 30 July is characterised by winds from southeast France. Figure 8 shows the chemical composition of modelled $\mathrm{OM}_{1}$ for both days. On 30 July, hydrophilic oxidation products of isoprene constitute most of the mass: they represent $26 \%$ of the concentrations against $9 \%$ on 16 July. However, organic nitrate (from monoterpene oxidation) represents as much as $35 \%$ of $\mathrm{OM}_{1}$ concentrations on 16 July, against only about $10 \%$ on 30 July, because the low winds of 16 July probably enhance the influence of $\mathrm{NO}_{x}$ emissions from ships on pollutant concentrations.

Although this organic nitrate is assumed to be hydrophobic, it may have undergone hydrolysis resulting in nitric acid and nonvolatile secondary organic aerosol that may change the hydrophilicity of organics and the organic composition, as detailed in Pye et al. (2015). 

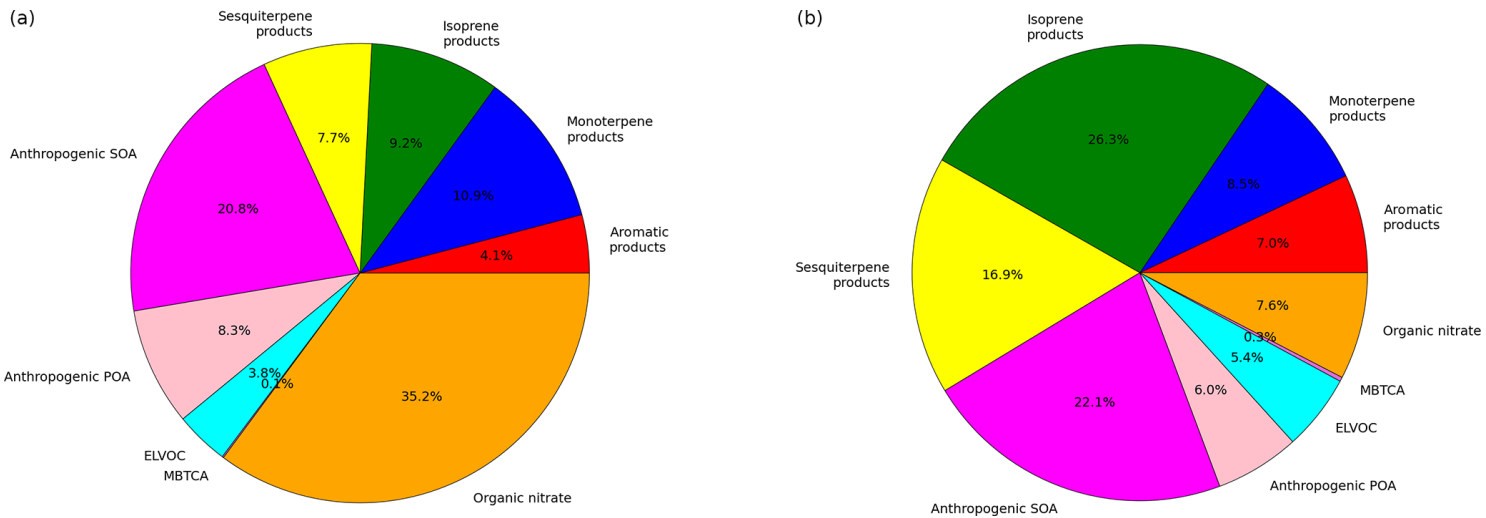

Figure 8. Simulated chemical composition of $\mathrm{OM}_{1}$ on 16 July (a) and on 30 July 2013 (b).
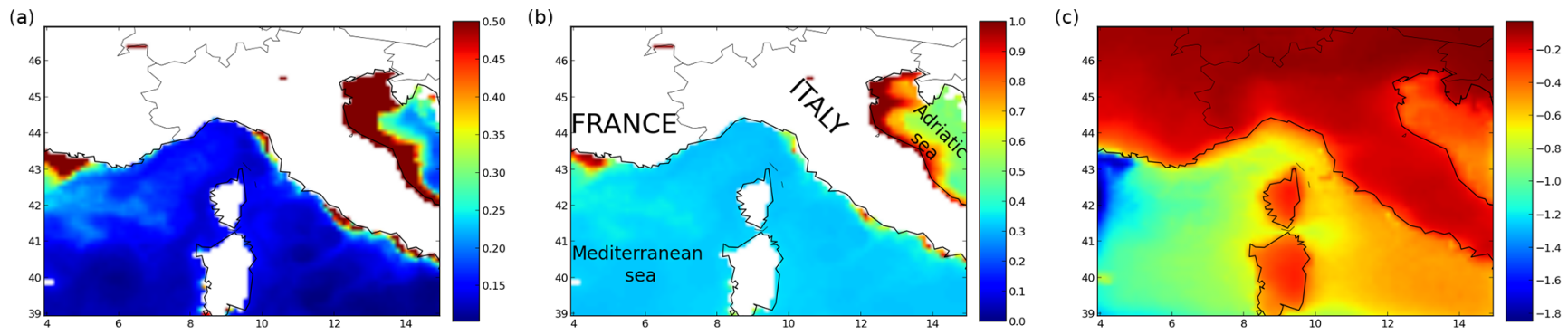

Figure 9. (a) Temporal average of chl $a$ in sea surface in units of $\mathrm{mg} \mathrm{m}^{-3}$ during the summer of 2013 (from 6 June to 3 August). (b) Organic mass fraction of emitted sea-spray aerosols of diameters between 0.01 and $0.1585 \mu \mathrm{m}$. (c) Relative difference $(\%)$ in the concentrations of $\mathrm{OM}_{1}$ between the base simulation and the simulation including organic sea-salt emissions.

\section{Impact of the biological activity of the Mediterranean Sea}

According to O'Dowd et al. (2004), organic aerosols of marine origin can contribute to organic $\mathrm{OM}_{1}$ concentrations especially near biologically productive waters. Particles of diameters larger than $1 \mu \mathrm{m}$ tend to contain mostly inorganic compounds, and the fraction of organic increases with decreasing diameter for particles of diameters smaller than $1 \mu \mathrm{m}$ (O'Dowd et al., 2004; Schwier et al., 2015).

Several studies found a correlation between the organic mass fraction of sea-spray aerosol $\left(\mathrm{OM}_{\mathrm{SSA}}\right)$ and the concentrations of oceanic parameters like $\operatorname{chl} a$, which is used as a proxy for biological activity and related ocean chemistry (O'Dowd et al., 2008; Gantt et al., 2011; Schwier et al., 2015). Several parameterisations exist to estimate the fraction of organics in primary marine aerosols. Whereas in the parameterisation of Schwier et al. (2015), which is designed for Aitken mode aerosols, the organic fraction depends not only on chl $a$ but also on the $10 \mathrm{~m}$ wind speed and the particle diameter in Gantt et al. (2012). OM $\mathrm{MSA}_{\mathrm{SS}}$ decreases with increasing $10 \mathrm{~m}$ wind speed, because for strong wind speeds, bubbles are not enough enriched by organic matter due to the wave breaking. Concerning the size dependence, Gantt et al. (2012) showed that the maximum organic fraction in the
Aitken and accumulation modes is about 80 to $90 \%$, while the fraction is less than $2 \%$ in the coarse mode.

The concentrations of the chl $a$ are obtained from monthly averaged MODIS/AQUA satellite data (https://oceandata.sci. gsfc.nasa.gov/MODIS-Aqua/L3SMI/, Hu et al., 2012), with a spatial resolution of $4 \mathrm{~km} \times 4 \mathrm{~km}$. They are shown in Fig. 9a.

Values are low, typical of oligotrophic conditions that characterise stratified surface Mediterranean waters in summer. The highest chl $a$ concentrations are recorded around the coastal zones meaning shallow water, places where sea currents bring cold waters with plants and nutrients from sea floor or brought from the rivers to the surface due to the rising slope of the sea floor.

Far from the coasts, the chl $a$ is more or less uniform (less than $0.2 \mathrm{mg} \mathrm{m}^{-3}$ ). The chl $a$ temporal average near Ersa is $0.14 \mathrm{mg} \mathrm{m}^{-3}$.

The emitted organic mass fraction of sea salt is shown in Fig. 9b using the parameterisation of Gantt et al. (2012) for aerosols of diameters between 0.01 and $0.1585 \mu \mathrm{m}$. The organic fraction map has almost the same spatial distribution as the chl $a$ map. The fraction of marine organic emissions is higher near the shores of the continent. The temporal average of emitted OM $_{S S A}$ near Ersa is detailed in Table 5 for aerosols of different sizes. As expected, the organic fraction 
Table 5. Temporal averages of $\mathrm{OM}_{\mathrm{SSA}}$ near Ersa using the parameterisation of Gantt et al. (2012) as a function of aerosol particle diameter, over the summer of 2013 (from 6 June to 3 August).

\begin{tabular}{lrrrr}
\hline Diameter range $(\mu \mathrm{m})$ & {$[0.01,0.1585]$} & {$[0.1585,1.0]$} & {$[1.0,2.5119]$} & {$[2.5119,10.0]$} \\
\hline Temporal average of OM $\mathrm{SSA}$ in Ersa & 0.31 & 0.22 & 0.02 & 0.01 \\
\hline
\end{tabular}

is higher for aerosols in the Aitken mode $(\sim 0.31)$ than in the accumulation mode $(\sim 0.22)$ than in the coarse one $(\sim 0.01)$. These simulated organic fractions are consistent with the fraction obtained by the Schwier et al. (2015) parameterisation for the Aitken mode (0.23). They are also consistent with the average fraction of 0.24 found experimentally by Schwier et al. (2015) using pelagic mesocosms in the bay of Calvi (Corsica, France) during the summer of 2012 (an average fraction of 0.24).

A simulation was performed using the organic fraction of primary marine emissions computed with the Gantt et al. (2012) parameterisation, in order to assess the impact of the marine organics on the concentrations of organics $\mathrm{OM}_{1}$. The organic emissions are affected to a new species called "SSorg", which is assumed to be hydrophobic and not very volatile. The properties are detailed in Table 3. The values are assumed to be the same as those taken for methyl nitrobenzoic acid in the model, following the lack of data characterising the properties of these species. Secondary marine OM formation is not taken into account.

Figure 9c shows the relative difference of organic $\mathrm{OM}_{1}$ concentrations between the base simulation and the simulation including organic sea salt. The contribution of the organic sea-salt emissions to organic $\mathrm{OM}_{1}$ is small (a few percent at the maximum) and localised above the sea. On average over the marine domain, the organic sea-salt emissions contribute to about $1.8 \%$ of the organic $\mathrm{OM}_{1}$ concentrations. Despite the larger chl $a$ and organic fraction over the Adriatic Sea, the contribution of SSorg to $\mathrm{OM}_{1}$ concentrations is not as high as the one over the Mediterranean Sea in the south of France. This is due to the fact that the surface wind-driven flux of sea salts over the Adriatic Sea is not as important as over the Mediterranean Sea in the south of France.

\section{Conclusions}

This paper presents comparisons of modelled organic concentrations and properties to surface measurements performed at Ersa (Cape Corsica, France) during the summers of 2012 and 2013. The air-quality model of the Polyphemus platform is used with a surrogate approach to model SOA. The previously published surrogate approach is modified to better represent observed OA properties, by taking into account the formation of ELVOCs and organic nitrate from monoterpene oxidation. The concentrations of organic matter compare well to the measurements performed with an ACSM.
During the summer 2013, the added surrogates led to a significant increase of mass concentrations: they contributed to $15 \%$ of the $\mathrm{OM}_{1}$ mass for ELVOC, $20 \%$ for organic nitrate from monoterpene oxidation and $0.2 \%$ for MBTCA. In agreement with ${ }^{14} \mathrm{C}$ measurements, most of the organic aerosol is from non-fossil (biogenic) origin. The inclusion in the model of ELVOC and organic nitrate formation greatly improves the modelled oxidation state of particles, as assessed by the OM/OC and O/C ratios. Despite the model improvements, these ratios remain underestimated compared to measurements (2.18 simulated against 2.43 measured for $\mathrm{OM} / \mathrm{OC}$ and 0.73 simulated against 0.99 measured for $\mathrm{O} / \mathrm{C})$. However, the ratios are better modelled by assuming that a surrogate species from isoprene oxidation is an organosulfate (2.37 simulated for $\mathrm{OM} / \mathrm{OC}$ and 0.84 for $\mathrm{O} / \mathrm{C}$ ), suggesting that further work should focus on a better description of organosulfate formation. Although an organic acid, MBTCA, was introduced as a second-generation product of MT, its yield should be revisited to include the formation of several carboxylic acids rather than a single species. Concerning the hydrophilic properties of aerosols, as much as $64 \%$ of organic carbon is soluble. Therefore, taking into account the hydrophilic properties of aerosols is crucial to model the partitioning of aerosols between the gas and particle phases. The average concentration of water soluble organic carbon is relatively well modelled by comparison to measurements performed using a PILS-TOC-UV (with a mean value of $1.0 \mu \mathrm{gC} \mathrm{m}{ }^{-3}$ in the measurements and $0.9 \mu \mathrm{gC} \mathrm{m}^{-3}$ in the model) over the second half of July 2013. Daily comparisons to measurements show that although organic nitrate is assumed hydrophobic here, its hydrolysis should be modelled to better represent the hydrophilic properties of organics. There are other pathways and mechanisms that are not considered in the model, but that may change the concentrations and hydrophilicity of organics (Shrivastava et al., 2017). For example, salting effects (via activity coefficients) are not considered, although inorganics provide a mass onto which hydrophilic organic surrogates may condense. Furthermore, pathways such as the aging chemistry of VOCs and I/S-VOCs from biomass burning (wildfires) and organic cloud processing are not considered. However, these pathways may be relatively low during the studied periods. Marine organic aerosols were added to the model, with a parameterisation depending on chlorophyll $a, 10 \mathrm{~m}$ wind speed and particle diameters. Although the emitted organic fraction is high for particles of small diameters (Aitken and accumulation modes), its contribution to the total organic mass $\mathrm{OM}_{1}$ 
is only a few percents at the maximum. Its contribution over the continent is always lower than 1 to $2 \%$.

Data availability. Data can be requested from the corresponding author (mounir.chrit@enpc.fr). 
Table A1. Kinetic constants used in the ELVOC kinetic model.

\begin{tabular}{lr}
\hline Kinetic constant & Value $\left(\mathrm{cm}^{3} \mathrm{~s}^{-1}\right.$ or s$\left.^{-1}\right)$ \\
\hline$k_{1}$ & $8.4 \times 10^{-17}$ \\
$k_{2}$ & $1.0 \times 10^{-12}$ \\
$k_{3}$ & $4.7 \times 10^{-12}$ \\
$k_{4}$ & $2.7 \times 10^{-11}$ \\
$k_{5}$ & $5.0 \times 10^{-11}$ \\
$k_{6}$ & $4.7 \times 10^{-12}$ \\
$k_{\mathrm{H} / \mathrm{O}_{2}}$ & 0.5 \\
\hline
\end{tabular}

\section{Appendix A: Formation of ELVOC}

The reactions involved in the formation of ELVOCs are

$$
\begin{aligned}
& \mathrm{MT}+\mathrm{O}_{3} \overrightarrow{k_{1}} \quad \gamma_{\mathrm{RO}_{2}} \cdot \mathrm{RO}_{2}+\left(1-\lambda-\gamma_{\mathrm{RO}_{2}}\right) \cdot \mathrm{R}^{\prime} \mathrm{O}_{2} \\
& \quad+\mathrm{OH}+0.001 \mathrm{HO}_{2} \\
& \mathrm{R}^{\prime} \mathrm{O}_{2} \overrightarrow{\mathrm{H}_{\mathrm{H}} \mathrm{O}_{2}} \alpha \cdot \mathrm{R}^{\prime \prime} \mathrm{O}_{2} \\
& \mathrm{R}^{\prime \prime} \mathrm{O}_{2} \overrightarrow{k_{\mathrm{H} / \mathrm{O}_{2}}} \alpha \cdot \mathrm{R}^{\prime \prime \prime} \mathrm{O}_{2} \\
& \mathrm{R}^{\prime \prime \prime} \mathrm{O}_{2} \overrightarrow{\mathrm{k}_{\mathrm{H}} \mathrm{O}_{2}} \alpha \cdot \mathrm{R}_{\mathrm{elvoc}} \mathrm{O}_{2} \\
& \mathrm{RO}_{2}+\mathrm{R}^{\prime} \mathrm{O}_{2} \overrightarrow{k_{2}} \text { products } \\
& \mathrm{RO}_{2}+\mathrm{NO}_{\overrightarrow{k_{3}}} \delta \cdot \mathrm{RO}_{2} \\
& \mathrm{RO}_{2}+\mathrm{HO}_{2} \overrightarrow{k_{4}} \text { products } \\
& \mathrm{R}_{\mathrm{elvoc}} \mathrm{O}_{2}+\mathrm{RO} 2\left(\text { or } \mathrm{HO}_{2}\right) \overrightarrow{k_{5}} \beta \cdot \text { monomer } \\
& \quad+(1-\beta) \cdot \text { dimer } \\
& \mathrm{R}_{\mathrm{elvoc}} \mathrm{O}_{2}+\mathrm{NO} \overrightarrow{k_{6}} \chi \cdot \text { nitrate }
\end{aligned}
$$

After numerous combinations, the stoichiometric coefficients of Eq. (AR1) were determined, such as reproducing the observations of Ehn et al. (2014) for both the low- $\mathrm{NO}_{x}$ and high- $\mathrm{NO}_{x}$ regimes (Table A2).

For model validation, comparisons are made to the experiments of Ehn et al. (2014). In the low- $\mathrm{NO}_{x}$ regime, the experiments of Ehn et al. (2014) lasted $45 \mathrm{~min}$ and the initial ozone concentration was $80 \mathrm{ppb}$. In the model, we modified the initial concentration of $\alpha$-pinene from 0 to $11 \mathrm{ppb}$ to reproduce the observations. Figure A1, which shows one-fifth of the ELVOC concentrations as a function of the $\alpha$-pinene reaction rate, reproduces successfully the extended data in Fig. 10 of Ehn et al. (2014). According to Fig. A1, the increase of peroxy radicals has a square root dependence while ELVOC monomers and dimers evolve nearly linearly. Therefore, the total ELVOC concentration has a near-linear dependence on the amount of $\alpha$-pinene reacting with $\mathrm{O}_{3}$ indicative of firstgeneration oxidation products. These findings are consistent qualitatively and quantitatively with Ehn et al. (2014) measured and modelled results.

In the high- $\mathrm{NO}_{x}$ regime, the experiments of Ehn et al. (2014) also lasted $45 \mathrm{~min}$ and the initial ozone and $\alpha$-pinene

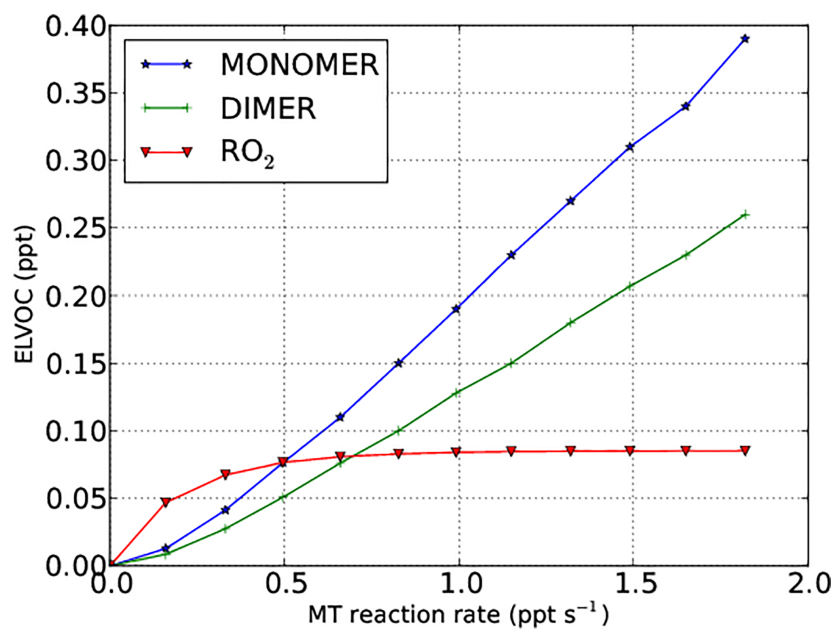

Figure A1. ELVOC concentrations as a function of the $\alpha$-pinene reaction rate for the low- $\mathrm{NO}_{x}$ experiment.

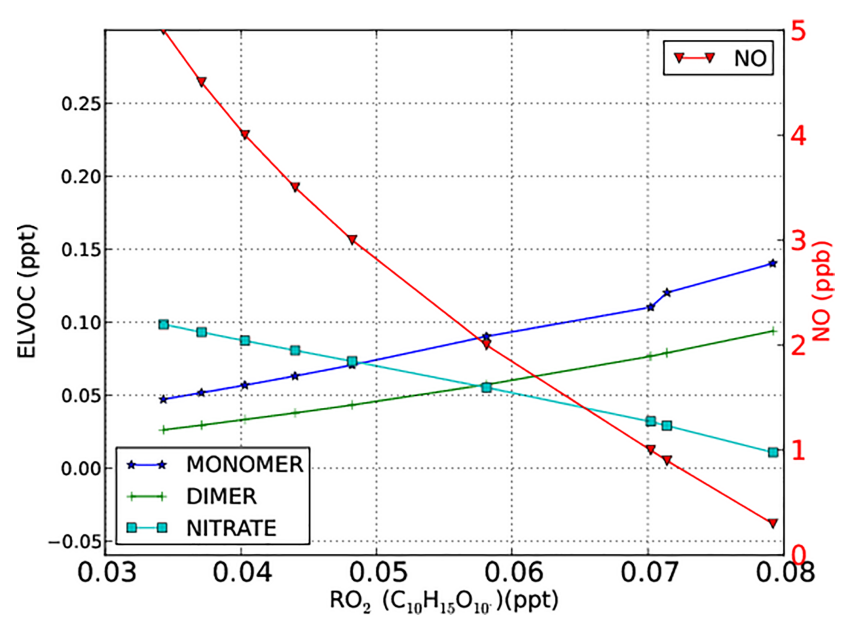

Figure A2. ELVOC concentration as a function of the $\mathrm{RO}_{2}$ concentration in the high- $\mathrm{NO}_{x}$ regime.

concentrations were 80 and 5 ppb respectively. The initial NO concentration was changed gradually from 0.3 to $5 \mathrm{ppb}$. Figure A2, which shows one-fifth of the ELVOC as a function of the $\mathrm{RO}_{2}$ concentration, reproduces successfully the extended data in Fig. 10 of Ehn et al. (2014). While increasing NO concentration, both monomer and dimer concentrations decrease rapidly as expected because a fraction of peroxy radicals is consumed by the NO reaction. Moreover, the dimer concentration decreases rapidly while the monomer concentration decreases more slowly. Simultaneously, the organic nitrate concentration increases with increasing NO. 
Table A2. Stoichiometric coefficients used in the model.

\begin{tabular}{lrrrrrrr}
\hline Stoichiometric coefficient & $\gamma_{\mathrm{RO}_{2}}$ & $\lambda$ & $\alpha$ & $\delta$ & $\beta$ & $\chi$ & $\phi$ \\
\hline Value & 0.0002 & 0.0998 & 1.0 & 0.995 & 0.6 & 0.00012 & 0.00001 \\
\hline
\end{tabular}

Table B1. Kinetic constants used in the organic nitrate formation mechanism.

\begin{tabular}{ll}
\hline Kinetic constant & Value $\left(\mathrm{cm}^{3} \mathrm{~s}^{-1}\right.$ or s$\left.^{-1}\right)$ \\
\hline$k_{1}^{\prime}$ & $\alpha$-Pinene $\left(1.21 \times 10^{-11} \exp (444 / T)\right)$ \\
& Limonene $\left(4.2010^{-11} \exp (401 / T)\right)$ \\
& $\beta$-Pinene $\left(2.38 \times 10^{-11} \exp (357 / T)\right)$ \\
& Humulene $\left(2.93 \times 10^{-10}\right)$ \\
$k_{2}^{\prime}$ & $2.27 \times 10^{-11} \exp (435 / T)$ \\
$k_{3}^{\prime}$ & $\alpha$-Pinene $\left(1.19 \times 10^{-12} \exp (490 / T)\right)$ \\
& Limonene $\left(1.22 \times 10^{-11}\right)$ \\
& $\beta$-Pinene $\left(2.51 \times 10^{-12}\right)$ \\
$k_{4}^{\prime}$ & Humulene $\left(1.33 \times 10^{-12} \exp (490 / T)\right)$ \\
$k_{5}^{\prime}$ & $2.6 \times 10^{-12} \exp (380 / T)$ \\
$k_{6}^{\prime}$ & $2.65 \times 10^{-13} \exp (1300 / T)$ \\
$k_{7}^{\prime}$ & $2.3 \times 10^{-12}$ \\
\hline
\end{tabular}

\section{Appendix B: Formation of organic nitrate}

The formation of organic nitrate (orgNIT) from MT is modelled with the following reactions:

$$
\begin{aligned}
& \text { Terpene }+\mathrm{OH} \overrightarrow{k_{1}^{\prime}} \text { TERPRO }_{2} \\
& \mathrm{TERPRO}_{2}+\mathrm{NO} \overrightarrow{k_{2}^{\prime}} 0.201 \text { orgNIT } \\
& \mathrm{MT}+\mathrm{NO}_{3} \overrightarrow{k_{3}^{\prime}} \mathrm{TERPNRO}_{2} \\
& \mathrm{TERPNRO}_{2}+\mathrm{NO} \overrightarrow{k_{4}^{\prime}} 0.688 \text { orgNIT + products } \\
& \mathrm{TERPNRO}_{2}+\mathrm{HO}_{2} \overrightarrow{k_{5}^{\prime}} \text { orgNIT + products } \\
& \mathrm{TERPNRO}_{2}+\mathrm{NO}_{3} \overrightarrow{k_{6}^{\prime}} 0.422 \text { orgNIT + products } \\
& \mathrm{TERPNRO}_{2}+\mathrm{RO}_{2} \overrightarrow{k_{7}^{\prime}}(1-0.578 \delta) \text { orgNIT + products }
\end{aligned}
$$$$
\text { where } \delta=50 \%
$$

\section{Appendix C: Statistic indicators and criteria}

The statistic indicators used in this paper are described in Table $\mathrm{C} 1$. The performance and goal criteria used in this paper are described in Table $\mathrm{C} 2$.
Table C1. Definitions of the statistics used in this work. $\left(o_{i}\right)_{i}$ and $\left(c_{i}\right)_{i}$ are the observed and the simulated concentrations at time and location $i$ respectively. $n$ is the number of data.

\begin{tabular}{ll}
\hline Statistic indicator & Definition \\
\hline Root mean square error (RMSE) & $\sqrt{\frac{1}{n} \sum_{i=1}^{n}\left(c_{i}-o_{i}\right)^{2}}$ \\
Correlation (Corr) & $\frac{\sum_{i=1}^{n}\left(c_{i}-\bar{c}\right)\left(o_{i}-\bar{o}\right)}{\sqrt{\sum_{i=1}^{n}\left(c_{i}-\bar{c}\right)^{2}} \sqrt{\sum_{i=1}^{n}\left(o_{i}-\bar{o}\right)^{2}}}$ \\
Mean fractional bias (MFB) & $\frac{1}{n} \sum_{i=1}^{n} \frac{c_{i}-o_{i}}{\left(c_{i}+o_{i}\right) / 2}$ \\
Mean fractional error (MFE) & $\frac{1}{n} \sum_{i=1}^{n} \frac{c_{i}-o_{i}}{\left(c_{i}+o_{i}\right) / 2}$ \\
\hline
\end{tabular}

Table C2. Boylan and Russel criteria.

\begin{tabular}{lrr}
\hline Criteria & Performance criterion & Goal criterion \\
\hline MFB & $\leq 60 \%$ & $\leq 30 \%$ \\
MFE & $\leq 75 \%$ & $\leq 50 \%$ \\
\hline
\end{tabular}

\section{Appendix D: Sensitivity to ELVOC yield}

The ELVOC yield in the reference simulation is $11 \%$. Two sensitivity simulations are performed, using a lower bound (3\%; Jokinen et al., 2015) and a higher bound (18\%; Ehn et al., 2014).

The comparison of $\mathrm{OM}_{1}$ concentrations is shown in Fig. D1 and the statistical evaluation is shown in Table D1. The correlation between the measurements and the simulation is not modified by the ELVOC yield. However, the higher the yield is, the closer to zero the bias is (it decreases from -26 to $-7 \%$ ) and the lower the error MFE. However, the lower RMSE is obtained with a yield of $11 \%$ $\left(1.53 \mu \mathrm{g} \mathrm{m}^{-3}\right.$ with a yield of $11 \%$ against $1.54 \mu \mathrm{g} \mathrm{m}^{-3}$ with a yield of $3 \%$ and $1.59 \mathrm{\mu g} \mathrm{m}^{-3}$ with a yield of $18 \%$ ).

The simulated composition of $\mathrm{OM}_{1}$ using ELVOC yields of 3 and $18 \%$ are shown in Fig. D2. Using an ELVOC yield of $3 \%(18 \%)$, the ELVOCs represent $4.7 \%$ (22.9\%) of the $\mathrm{OM}_{1}$ mass.

The $\mathrm{OM} / \mathrm{OC}$ and $\mathrm{O} / \mathrm{C}$ ratios are plotted using the three yields $(3,11$ and $18 \%)$ in Fig. D3. The simulated means of the two ratios using the three ELVOC yields (3,11 and $18 \%$ ) are shown in Table D2. The ratios using the upper bound of ELVOC yields are the closest to the measurements. The $\mathrm{OM} / \mathrm{OC}$ and $\mathrm{O} / \mathrm{C}$ ratios may be higher when organosulfate is considered (Sect. 4.3). 


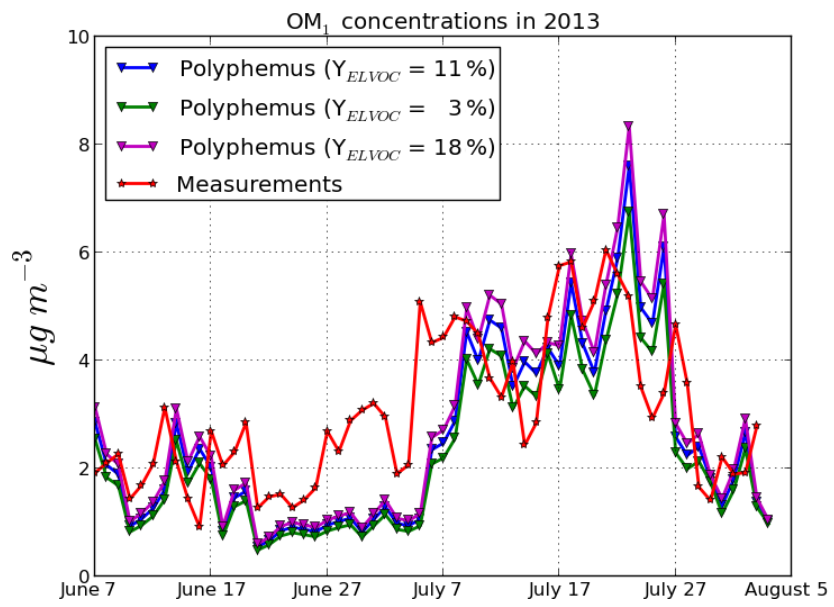

Figure D1. Simulated daily concentrations of $\mathrm{OM}_{1}$ using a molar ELVOC yield of $11 \%$ (blue plot, reference simulation), $18 \%$ (magenta plot) and $3 \%$ (green plot).

Table D1. Statistics of model to measurements comparisons for organic concentrations in particles of diameters lower than $1 \mu \mathrm{m}$ during the summer campaign of 2013 using an ELVOC molar yield of 3, 11 (reference) and $18 \% . \bar{s}$ represents the simulated mean concentrations. The observed mean concentration is $\bar{o}=2.89 \mu \mathrm{g} \mathrm{m}^{-3}$.

\begin{tabular}{lrrrrr}
\hline ELVOC yield $(\%)$ & $\bar{s}\left(\mu \mathrm{g} \mathrm{m}^{-3}\right)$ & $\left.\operatorname{RMSE}\left(\mu \mathrm{g} \mathrm{m}^{-3}\right)\right]$ & Correlation $(\%)$ & MFB & MFE \\
\hline 03 & 2.30 & 1.54 & 67.2 & -0.26 & 0.52 \\
11 & 2.58 & 1.53 & 67.3 & -0.15 & 0.49 \\
18 & 2.82 & 1.59 & 67.2 & -0.07 & 0.47 \\
\hline
\end{tabular}

(a)

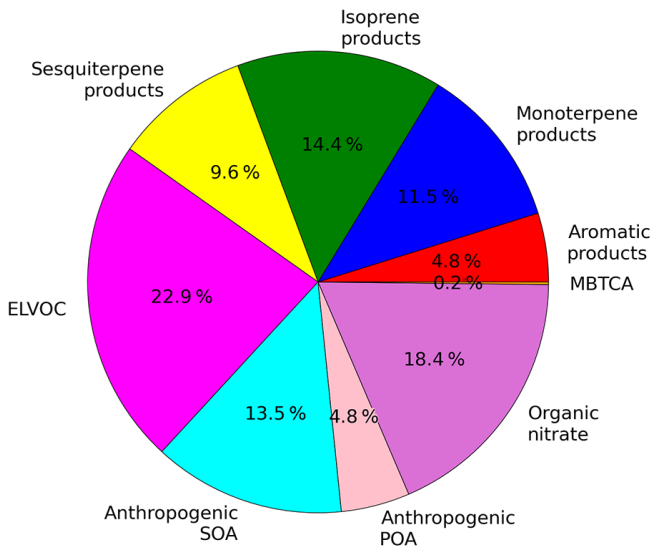

(b)

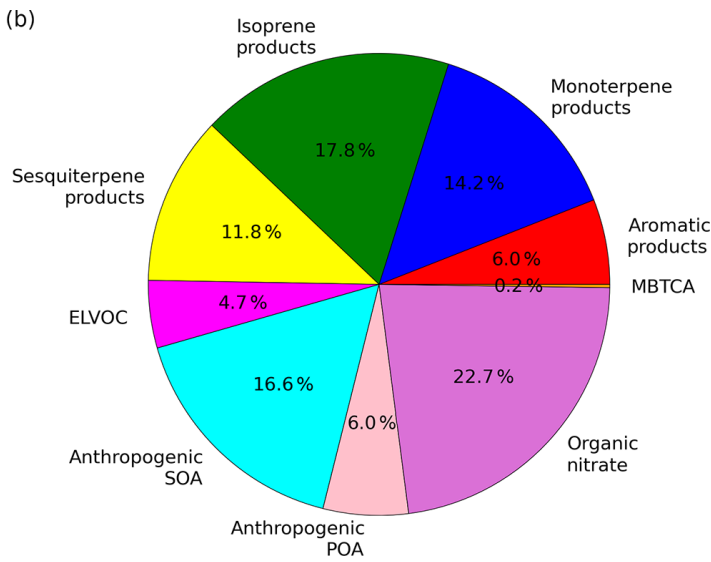

Figure D2. Simulated composition of $\mathrm{OM}_{1}$ using the upper (a) and lower (b) bounds of ELVOCs molar yields. 

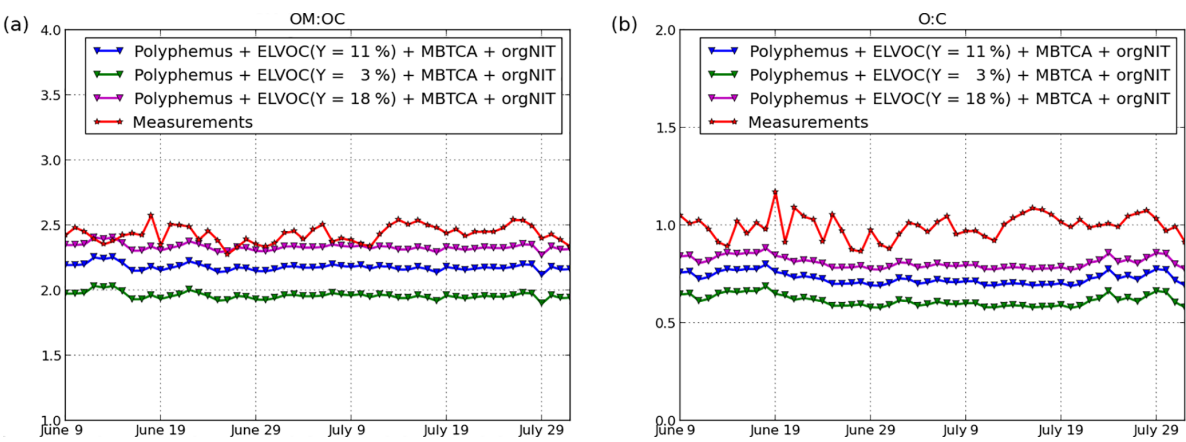

Figure D3. Comparisons of the OM / OC ratio (a) and the $\mathrm{O} / \mathrm{C}$ ratio (b) for simulations using an ELVOC molar yield of 3,11 and $18 \%$.

Table D2. Simulated means of the OM / OC and O / C ratios during the summer campaign of 2013 using an ELVOC molar yield of 3, 11 and $18 \%$. The measured means of $\mathrm{OM} / \mathrm{OC}$ and $\mathrm{O} / \mathrm{C}$ are 2.43 and 0.99 respectively.

\begin{tabular}{lrc}
\hline ELVOC yield (\%) & OM / OC & O / C \\
\hline 3 & 1.96 & 0.61 \\
11 & 2.18 & 0.73 \\
18 & 2.33 & 0.81 \\
\hline
\end{tabular}


Competing interests. The authors declare that they have no conflict of interest.

Special issue statement. This article is part of the special issue "CHemistry and AeRosols Mediterranean EXperiments (ChArMEx) (ACP/AMT inter-journal SI)". It is not associated with a conference.

Acknowledgements. This research has received funding from the French National Research Agency (ANR) projects SAF-MED (grant ANR-12-BS06-0013). This work is part of the ChArMEx project supported by ADEME, CEA, CNRS-INSU and MétéoFrance through the multidisciplinary programme MISTRALS (Mediterranean Integrated Studies aT Regional And Local Scales). The station at Ersa was partly supported by the CORSiCA project funded by the Collectivite Territoriale de Corse through the Fonds Européen de Développement Régional of the European Operational Program 2007-2013 and the Contrat de Plan Etat-Région. Eric Hamounou and François Dulac are acknowledged for their great help in organising the campaigns at Ersa. CEREA is a member of the Institut Pierre-Simon Laplace (IPSL).

Edited by: Barbara Ervens

Reviewed by: three anonymous referees

\section{References}

Albriet, B., Sartelet, K., Lacour, S., Carissimo, B., and Seigneur, C.: Modelling aerosol number distributions from a vehicle exhaust with an aerosol CFD model, Atmos. Environ., 44, 1126-1137, https://doi.org/10.1016/j.atmosenv.2009.11.025, 2010.

Arndt, J., Sciare, J., Mallet, M., Roberts, G. C., Marchand, N., Sartelet, K., Sellegri, K., Dulac, F., Healy, R. M., and Wenger, J. C.: Sources and mixing state of summertime background aerosol in the north-western Mediterranean basin, Atmos. Chem. Phys., 17, 6975-7001, https://doi.org/10.5194/acp17-6975-2017, 2017.

Bean, J. K. and Hildebrandt Ruiz, L.: Gas-particle partitioning and hydrolysis of organic nitrates formed from the oxidation of $\alpha$-pinene in environmental chamber experiments, Atmos. Chem. Phys., 16, 2175-2184, https://doi.org/10.5194/acp-162175-2016, 2016.

Bessagnet, B., Menut, L., Curci, G., Hodzic, A., Guillaume, B., Liousse, C., Moukhtar, S., Pun, B., Seigneur, C., and Schulz, M.: Regional modeling of carbonaceous aerosols over Europe-focus on secondary organic aerosols, J. Atmos. Chem., 61, 175-202, https://doi.org/10.1007/s10874-009-9129-2, 2008.

Boylan, J. W. and Russell, A. G.: PM and light extinction model performance metrics, goals, and criteria for threedimensional air quality models, Atmos. Environ., 40, 49464959, https://doi.org/10.1016/j.atmosenv.2005.09.087, 2006.

Budisulistiorini, S. H., Li, X., Bairai, S. T., Renfro, J., Liu, Y., Liu, Y. J., McKinney, K. A., Martin, S. T., McNeill, V. F., Pye, H. O. T., Nenes, A., Neff, M. E., Stone, E. A., Mueller, S., Knote, C., Shaw, S. L., Zhang, Z., Gold, A., and Surratt, J. D.: Examining the effects of anthropogenic emissions on isoprene- derived secondary organic aerosol formation during the 2013 Southern Oxidant and Aerosol Study (SOAS) at the Look Rock, Tennessee ground site, Atmos. Chem. Phys., 15, 8871-8888, https://doi.org/10.5194/acp-15-8871-2015, 2015.

Carlton, A. G., Bhave, P. V., Napelenok, S. L., Edney, E. O., Sarwar, G., Pinder, R. W., Pouliot, G. A., and Houyoux, M.: Model representation of secondary organic aerosol in CMAQv4.7, Environ. Sci. Technol., 44, 8553-8560, https://doi.org/10.1021/es100636q, 2010.

Cholakian, A., Beekmann, M., Colette, A., Coll, I., Siour, G., Sciare, J., Marchand, N., Pey, J., Gros, V., Sauvage, S., Sellegri, K., Colomb, A., Sartelet, K., and Dulac, F.: Simulation of fine organic aerosols in the western Mediterranean area during the ChArMEx 2013 summer campaign, Atmos. Chem. Phys. Discuss., submitted, 2017.

Couvidat, F. and Sartelet, K.: The Secondary Organic Aerosol Processor (SOAP v1.0) model: a unified model with different ranges of complexity based on the molecular surrogate approach, Geosci. Model Dev., 8, 1111-1138, https://doi.org/10.5194/gmd8-1111-2015, 2015.

Couvidat, F. and Seigneur, C.: Modeling secondary organic aerosol formation from isoprene oxidation under dry and humid conditions, Atmos. Chem. Phys., 11, 893-909, https://doi.org/10.5194/acp-11-893-2011, 2011.

Couvidat, F., Debry, É., Sartelet, K., and Seigneur, C.: A hydrophilic/hydrophobic organic $\left(\mathrm{H}^{2} \mathrm{O}\right)$ model: Model development, evaluation and sensitivity analysis, J. Geophys. Res., 117, D10304, https://doi.org/10.1029/2011JD017214, 2012.

Couvidat, F., Kim, Y., Sartelet, K., Seigneur, C., Marchand, N., and Sciare, J.: Modeling secondary organic aerosol in an urban area: application to Paris, France, Atmos. Chem. Phys., 13, 983-996, https://doi.org/10.5194/acp-13-983-2013, 2013a.

Couvidat, F., Sartelet, K., and Seigneur, C.: Investigating the impact of aqueous-phase chemistry and wet deposition on organic aerosol formation using a molecular surrogate modeling approach, Environ. Sci. Technol., 47, 914-922, https://doi.org/10.1021/es3034318, 2013b.

Crounse, J. D., Nielsen, L. B., Jørgensen, S., Kjaergaard, H. G., and Wennberg, P. O.: Autoxidation of organic compounds in the atmosphere, J. Phys. Chem. Lett., 4, 3513-3520, https://doi.org/10.1021/jz4019207, 2013.

Debry, É., Seigneur, C., and Sartelet, K.: Organic aerosols in the air quality platform Polyphemus: oxidation pathways, hydrophilic/hydrophobic partitioning and oligomerization, International Aerosol Modeling Algorithms, univ. of California, Davis, 2007.

Di Biagio, C., Doppler, L., Gaimoz, C., Grand, N., Ancellet, G., Raut, J.-C., Beekmann, M., Borbon, A., Sartelet, K., Attié, J.-L., Ravetta, F., and Formenti, P.: Continental pollution in the western Mediterranean basin: vertical profiles of aerosol and trace gases measured over the sea during TRAQA 2012 and SAFMED 2013, Atmos. Chem. Phys., 15, 9611-9630, https://doi.org/10.5194/acp-15-9611-2015, 2015.

Donahue, N. M., Epstein, S. A., Pandis, S. N., and Robinson, A. L.: A two-dimensional volatility basis set: 1. organic-aerosol mixing thermodynamics, Atmos. Chem. Phys., 11, 3303-3318, https://doi.org/10.5194/acp-11-3303-2011, 2011.

Donahue, N. M., Robinson, A. L., Stanier, C. O., and Pandis, S. N.: Coupled partitioning, dilution, and chemical aging of 
semivolatile organics, Environ. Sci. Technol., 40, 2635-2643, https://doi.org/10.1021/es052297c, 2006.

Ehn, M., Thornton, J., Kleist, E., Sipilä, M., Junninen, H., Pullinen, I., Springer, M., Rubach, F., Tillmann, R., Lee, B., Lopez-Hilfiker, F., Andres, S., Acir, I., Rissanen, M., Jokinen, T., Schobesberger, S., Kangasluoma, J., Kontkanen, J., Nieminen, T., Kurtén, T., Nielsen, L. B., Jørgensen, S., Kjaergaard, H. G., Canagaratna, M., Dal Maso, M., Berndt, T., Petäjä, T., Wahner, A., Kerminen, V., Kulmala, M., Worsnop, D. R., Wildt, J., and Mentel, T. F.: A large source of lowvolatility secondary organic aerosol, Nature, 506, 476-479, https://doi.org/10.1038/nature13032, 2014.

El Haddad, I., Marchand, N., Wortham, H., Piot, C., Besombes, J.L., Cozic, J., Chauvel, C., Armengaud, A., Robin, D., and Jaffrezo, J.-L.: Primary sources of $\mathrm{PM}_{2.5}$ organic aerosol in an industrial Mediterranean city, Marseille, Atmos. Chem. Phys., 11, 2039-2058, https://doi.org/10.5194/acp-11-2039-2011, 2011.

El Haddad, I., D’Anna, B., Temime-Roussel, B., Nicolas, M., Boreave, A., Favez, O., Voisin, D., Sciare, J., George, C., Jaffrezo, J.-L., Wortham, H., and Marchand, N.: Towards a better understanding of the origins, chemical composition and aging of oxygenated organic aerosols: case study of a Mediterranean industrialized environment, Marseille, Atmos. Chem. Phys., 13, 78757894, https://doi.org/10.5194/acp-13-7875-2013, 2013.

Fredenslund, A., Jones, R. L., and Prausnitz, J. M.: GroupContribution Estimation of Activity Coefficients in Nonideal Liquid Mixtures, AIChE J., 21, 1086-1099, 1975.

Freney, E., Sellegri, K., Chrit, M., Adachi, K., Brito, J., Waked, A., Borbon, A., Colomb, A., Dupuy, R., Pichon, J.-M., Bouvier, L., Delon, C., Jambert, C., Durand, P., Bourianne, T., Gaimoz, C., Triquet, S., Féron, A., Beekmann, M., Dulac, F., and Sartelet, K.: Aerosol composition and the contribution of SOA formation over Mediterranean forests, Atmos. Chem. Phys. Discuss., https://doi.org/10.5194/acp-2017-482, in review, 2017.

Fry, J. L., Kiendler-Scharr, A., Rollins, A. W., Wooldridge, P. J., Brown, S. S., Fuchs, H., Dubé, W., Mensah, A., dal Maso, M., Tillmann, R., Dorn, H.-P., Brauers, T., and Cohen, R. C.: Organic nitrate and secondary organic aerosol yield from $\mathrm{NO}_{3}$ oxidation of $\beta$-pinene evaluated using a gas-phase kinetics/aerosol partitioning model, Atmos. Chem. Phys., 9, 14311449, https://doi.org/10.5194/acp-9-1431-2009, 2009.

Fuzzi, S., Andreae, M. O., Huebert, B. J., Kulmala, M., Bond, T. C., Boy, M., Doherty, S. J., Guenther, A., Kanakidou, M., Kawamura, K., Kerminen, V.-M., Lohmann, U., Russell, L. M., and Pöschl, U.: Critical assessment of the current state of scientific knowledge, terminology, and research needs concerning the role of organic aerosols in the atmosphere, climate, and global change, Atmos. Chem. Phys., 6, 2017-2038, https://doi.org/10.5194/acp-6-2017-2006, 2006.

Gantt, B., Meskhidze, N., Facchini, M. C., Rinaldi, M., Ceburnis, D., and O'Dowd, C. D.: Wind speed dependent size-resolved parameterization for the organic mass fraction of sea spray aerosol, Atmos. Chem. Phys., 11, 8777-8790, https://doi.org/10.5194/acp-11-8777-2011, 2011.

Gantt, B., Johnson, M. S., Meskhidze, N., Sciare, J., Ovadnevaite, J., Ceburnis, D., and O'Dowd, C. D.: Model evaluation of marine primary organic aerosol emission schemes, Atmos. Chem. Phys., 12, 8553-8566, https://doi.org/10.5194/acp12-8553-2012, 2012.
GENEMIS: Technical Report, EUROTEC, annual report 1993 1994.

Guenther, A., Karl, T., Harley, P., Wiedinmyer, C., Palmer, P. I., and Geron, C.: Estimates of global terrestrial isoprene emissions using MEGAN (Model of Emissions of Gases and Aerosols from Nature), Atmos. Chem. Phys., 6, 3181-3210, https://doi.org/10.5194/acp-6-3181-2006, 2006.

Hatakeyama, S., Akimoto, H., and Washida, N.: Effect of temperature on the formation of photochemical ozone in a propene $\mathrm{NO}_{x}$ air irradiation system, J. Geophys. Res., 25, 1884-1890, 1991.

Hayes, P. L., Carlton, A. G., Baker, K. R., Ahmadov, R., Washenfelder, R. A., Alvarez, S., Rappenglück, B., Gilman, J. B., Kuster, W. C., de Gouw, J. A., Zotter, P., Prévôt, A. S. H., Szidat, S., Kleindienst, T. E., Offenberg, J. H., Ma, P. K., and Jimenez, J. L.: Modeling the formation and aging of secondary organic aerosols in Los Angeles during CalNex 2010, Atmos. Chem. Phys., 15, 5773-5801, https://doi.org/10.5194/acp-15-5773-2015, 2015.

Hoffmann, T., Odum, J. R., Bowman, F., Collins, D., Klockow, D., Flagan, R. C., and Seinfeld, J. H.: Formation of organic aerosols from the oxidation of biogenic hydrocarbon, J. Atmos. Chem., 26, 189-222, https://doi.org/10.1023/A:1005734301837, 1997.

Horowitz, L. W., Walters, S., Mauzerall, D. L., Emmons, L. K., Rasch, P. J., Granier, C., Tie, X., Lamarque, J.-F., Schultz, M. G., Tyndall, G. S., Orlando, J. J., and Brasseur, G. P.: A global simulation of tropospheric ozone and related tracers: Description and evaluation of MOZART, version 2, J. Geophys. Res., 108, 4784, https://doi.org/10.1029/2002JD002853, 2003.

Hoyle, C. R., Boy, M., Donahue, N. M., Fry, J. L., Glasius, M., Guenther, A., Hallar, A. G., Huff Hartz, K., Petters, M. D., Petäjä, T., Rosenoern, T., and Sullivan, A. P.: A review of the anthropogenic influence on biogenic secondary organic aerosol, Atmos. Chem. Phys., 11, 321-343, https://doi.org/10.5194/acp-11-3212011, 2011.

Hu, C., Lee, Z., and Franz, B.: Chlorophyll-a algorithms for oligotrophic oceans: A novel approach based on threeband reflectance difference, Atmos. Environ., 117, c01011, https://doi.org/10.1029/2011JC007395, 2012.

Hu, W. W., Campuzano-Jost, P., Palm, B. B., Day, D. A., Ortega, A. M., Hayes, P. L., Krechmer, J. E., Chen, Q., Kuwata, M., Liu, Y. J., de Sá, S. S., McKinney, K., Martin, S. T., Hu, M., Budisulistiorini, S. H., Riva, M., Surratt, J. D., St. Clair, J. M., Isaacman-Van Wertz, G., Yee, L. D., Goldstein, A. H., Carbone, S., Brito, J., Artaxo, P., de Gouw, J. A., Koss, A., Wisthaler, A., Mikoviny, T., Karl, T., Kaser, L., Jud, W., Hansel, A., Docherty, K. S., Alexander, M. L., Robinson, N. H., Coe, H., Allan, J. D., Canagaratna, M. R., Paulot, F., and Jimenez, J. L.: Characterization of a real-time tracer for isoprene epoxydiols-derived secondary organic aerosol (IEPOX-SOA) from aerosol mass spectrometer measurements, Atmos. Chem. Phys., 15, 11807-11833, https://doi.org/10.5194/acp-15-11807-2015, 2015.

Jaeglé, L., Quinn, P. K., Bates, T. S., Alexander, B., and Lin, J.-T.: Global distribution of sea salt aerosols: new constraints from in situ and remote sensing observations, Atmos. Chem. Phys., 11, 3137-3157, https://doi.org/10.5194/acp-11-3137-2011, 2011.

Jaoui, M. and Kamens, R. M.: Mass balance of gaseous and particulate products analysis from $\alpha$-pinene, $\mathrm{NO}_{x}$ air in the presence of natural sunlight, J. Geophys. Res., 107, 12541-12558, 2001.

Jaoui, M., Kleindienst, T. E., Docherty, K. S., Lewandowski, M., and Offenberg, J. H.: Secondary organic aerosol forma- 
tion from the oxidation of a series of sesquiterpenes: $\alpha$ cedrene, $\beta$-caryophyllene, $\alpha$-humulene and $\alpha$-farnesene with $\mathrm{O}_{3}, \mathrm{OH}$ and $\mathrm{NO}_{3}$-radicals, Environ. Chem., 10, 178-193, https://doi.org/10.1071/EN13025, 2013.

Jathar, S., Gordon, T., Henningan, C., Pye, H., Pouliot, G., Adams, P., Donahue, N., and Robinson, A.: Unspeciated organic emissions from combustion sources and their influence on the secondary organic aerosol budget in the United States. , P. Natl. Acad. Sci., 111, 10473-10478, https://doi.org/10.1073/pnas.1323740111, 2014.

Jathar, S. H., Cappa, C. D., Wexler, A. S., Seinfeld, J. H., and Kleeman, M. J.: Multi-generational oxidation model to simulate secondary organic aerosol in a 3-D air quality model, Geosci. Model Dev., 8, 2553-2567, https://doi.org/10.5194/gmd-8-2553-2015, 2015.

Jiang, H., Jang, M., Sabo-Attwood, T., and Robinson, S.: Oxidative potential of secondary organic aerosols produced from photooxidation of different hydrocarbons using outdoor chamber under ambient sunlight, Atmos. Environ., 131, 382-389, https://doi.org/10.1016/j.atmosenv.2016.02.016, 2016.

Jimenez, J. L., Canagaratna, M. R., Donahue, N. M., Prevot, A. S., Zhang, Q., Kroll, J. H., DeCarlo, P. F., Allan, J. D., Coe, H., Ng, N. L., Aiken, A. C., Docherty, K. D., Ulbrich, I., Grieshop, A. P., Robinson, A. L., Duplissy, J., Smith, J. D., Wilson, K. R., Lanz, V. A., Hueglin, C., Sun, Y. L., Tian, J., Laaksonen, A., Raatikainen, T., Rautiainen, J., Vaattovaara, P., Ehn, M., Kulmala, M., Tomlinson, J. M., Collins, D. R., Cubison, M. J., Dunlea, E. J., Huffman, J. A., Onasch, T. B., Alfarra, M. R., Williams, P. I., Bower, K., Kondo, Y., Schneider, J., Drewnick, F., Borrmann, S., Weimer, S., Demerjian, K., Salcedo, D., Cottrell, L., Griffin, R., Takami, A., Miyoshi, T., Hatakeyama, S., Shimono, A., Sun, J. Y., Zhang, Y. M., Dzepina, K., Kimmel, J. R., Sueper, D., Jayne, J. T., Herndon, S. C., Trimborn, A. M., Williams, L. R., Wood, E. C., Kolb, C. E., Middlebrook, A. M., Baltensperger, U., and Worsnop, D. R.: Evolution of organic aerosols in the atmosphere, Science, 326, 1525-1529, https://doi.org/10.1126/science.1180353, 2009.

Jokinen, T., Berndt, T., Makkonen, R., Kerminen, V., Junninen, H., Paasonen, P., Stratmann, F., Herrmann, H., Guenther, A. B., Worsnop, D. R., Kulmala, M., Ehn, M., and Sipiläb, M.: Production of extremely low volatile organic compounds from biogenic emissions: Measured yields and atmospheric implications, P. Natl. Acad. Sci., 112, 7123-7128, https://doi.org/10.1073/pnas.1423977112, 2015.

Kanakidou, M., Seinfeld, J. H., Pandis, S. N., Barnes, I., Dentener, F. J., Facchini, M. C., Van Dingenen, R., Ervens, B., Nenes, A., Nielsen, C. J., Swietlicki, E., Putaud, J. P., Balkanski, Y., Fuzzi, S., Horth, J., Moortgat, G. K., Winterhalter, R., Myhre, C. E. L., Tsigaridis, K., Vignati, E., Stephanou, E. G., and Wilson, J.: Organic aerosol and global climate modelling: a review, Atmos. Chem. Phys., 5, 1053-1123, https://doi.org/10.5194/acp-5-10532005, 2005.

Kim, Y., Couvidat, F., Sartelet, K., and Seigneur, C.: Comparison of different gas-phase mechanisms and aerosol modules for simulating particulate matter formation, J. Air Waste Manage. Assoc., 61, 1218-1226, https://doi.org/10.1080/10473289.2011.603999, 2011a.

Kim, Y., Sartelet, K., and Seigneur, C.: Formation of secondary aerosols over Europe: comparison of two gas-phase chemical mechanisms, Atmos. Chem. Phys., 11, 583-598, https://doi.org/10.5194/acp-11-583-2011, 2011 b.

Kim, Y., Sartelet, K., Seigneur, C., Charron, A., Besombes, J.-L., Jaffrezo, J.-L., Marchand, N., and Polo, L.: Effect of measurement protocol on organic aerosol measurements of exhaust emissions from gasoline and diesel vehicles, Atmos. Environ., 140, 176-187, https://doi.org/10.1016/j.atmosenv.2016.05.045, 2016.

Koo, B., Knipping, E., and Yarwood, G.: 1.5-Dimensional volatility basis set approach for modeling organic aerosol in CAMx and CMAQ, Atmos. Environ., 95, 158-164, https://doi.org/10.1016/j.atmosenv.2014.06.031, 2014.

Krechmer, J., Coggon, M., Massoli, P., Nguyen, T., Crounse, J., Hu, W., Day, D., Tyndall, G., Henze, D., Rivera-Rios, J., Nowak, J., Kimmel, J., Mauldin, R., Stark, H., Jayne, J., Sipila, M., Junninen, H., St.Clair, J., Zhang, X., Feiner, P., Zhang, L., Miller, D., Brune, W., Keutsch, F., Wennberg, P., Seinfeld, J., Worsnop, D., Jimenez, J., and Canagaratna, M.: Formation of low volatility organic compounds and secondary organic aerosol from isoprene hydroxyhydroperoxide low-NO oxidation, Environ. Sci. Technol., 49, 10330-10339, https://doi.org/10.1021/acs.est.5b02031, 2015.

Kristensen, K., Cui, T., Zhang, H., Gold, A., Glasius, M., and Surratt, J. D.: Dimers in $\alpha$-pinene secondary organic aerosol: effect of hydroxyl radical, ozone, relative humidity and aerosol acidity, Atmos. Chem. Phys., 14, 4201-4218, https://doi.org/10.5194/acp-14-4201-2014, 2014.

Kroll, J. H., Donahue, N. M., Jimenez, J. L., Kessler, S. H., Canagaratna, M., Wilson, K. R., Altieri, K. E., Mazzoleni, L. R., Wozniak, A. S., Bluhm, H., Mysak, E. R., Smith, J. D., E., K. C., and Worsnop, D. R.: Carbon oxidation state as a metric for describing the chemistry of atmospheric organic aerosol, Nature Chem., 3, 133-139, https://doi.org/10.1038/NCHEM.948, 2011.

Liggio, J. and Li, S.-M.: Organosulfate formation during the uptake of pinonaldehyde on acidic sulfate aerosols, Geophys. Res. Lett., 33, 13808-13812, https://doi.org/10.1029/2006GL026079, 2006.

Liggio, J., Li, S.-M., and McLaren, R.: Heterogeneous reactions of glyoxal on particulate matter: Identification of acetals and sulfate esters, Environ. Sci. Technol., 39, 1532-1541, https://doi.org/10.1021/es048375y, 2005.

Lin, J.-T., Martin, R. V., Boersma, K. F., Sneep, M., Stammes, P., Spurr, R., Wang, P., Van Roozendael, M., Clémer, K., and Irie, H.: Retrieving tropospheric nitrogen dioxide from the Ozone Monitoring Instrument: effects of aerosols, surface reflectance anisotropy, and vertical profile of nitrogen dioxide, Atmos. Chem. Phys., 14, 1441-1461, https://doi.org/10.5194/acp14-1441-2014, 2014.

Liu, J., D’Ambro, E. L., Lee, B. H., Lopez-Hilfiker, F., Zaveri, R., Rivera-Rios, J. C., Keutsch, F. N., Iyer, S., Kurtén, T., Zhang, Z., Gold, A., Surratt, J. D., Shilling, J. E., and Thornton, J. A.: Efficient isoprene secondary organic aerosol formation from a non IEPOX pathway, Environ. Sci. Technol., 50, 9872-9880, https://doi.org/10.1021/acs.est.6b0187, 2016.

Liu, S., Shilling, J. E., Song, C., Hiranuma, N., Zaveri, R. A., and Russell, L.: Hydrolysis of Organonitrate Functional Groups in Aerosol Particle, Aerosol Sci. Technol., 46, 1359-1369, https://doi.org/10.1080/02786826.2012.716175, 2012.

Mallet, M., Dulac, F., Formenti, P., Nabat, P., Sciare, J., Roberts, G., Pelon, J., Ancellet, G., Tanré, D., Parol, F., Denjean, C., 
Brogniez, G., di Sarra, A., Alados-Arboledas, L., Arndt, J., Auriol, F., Blarel, L., Bourrianne, T., Chazette, P., Chevaillier, S., Claeys, M., D’Anna, B., Derimian, Y., Desboeufs, K., Di Iorio, T., Doussin, J.-F., Durand, P., Féron, A., Freney, E., Gaimoz, C., Goloub, P., Gómez-Amo, J. L., Granados-Muñoz, M. J., Grand, N., Hamonou, E., Jankowiak, I., Jeannot, M., Léon, J.-F., Maillé, M., Mailler, S., Meloni, D., Menut, L., Momboisse, G., Nicolas, J., Podvin, T., Pont, V., Rea, G., Renard, J.-B., Roblou, L., Schepanski, K., Schwarzenboeck, A., Sellegri, K., Sicard, M., Solmon, F., Somot, S., Torres, B., Totems, J., Triquet, S., Verdier, N., Verwaerde, C., Waquet, F., Wenger, J., and Zapf, P.: Overview of the Chemistry-Aerosol Mediterranean Experiment/Aerosol Direct Radiative Forcing on the Mediterranean Climate (ChArMEx/ADRIMED) summer 2013 campaign, Atmos. Chem. Phys., 16, 455-504, https://doi.org/10.5194/acp-16455-2016, 2016.

Mallet, V. and Sportisse, B.: A comprehensive study of ozone sensitivity with respect to emissions over Europe with a chemistry-transport model, J. Geophys. Res., 110, D22302, https://doi.org/10.1029/2005JD006234, 2005.

May, A., Presto, A., Hennigan, C., Nguyen, N., Gordon, T., and Robinson, A.: Gas-particle partitioning of primary organic aerosol emissions: (1) Gasoline vehicle exhaust, Atmos. Environ., 77, 128-139, https://doi.org/10.1016/j.atmosenv.2013.04.060, 2013a.

May, A., Presto, A., Hennigan, C., Nguyen, N., Gordon, T., and Robinson, A.: Gas-Particle Partitioning of Primary Organic Aerosol Emissions: (2) Diesel Vehicles, Environ. Sci. Technol., 47, 8288-8296, https://doi.org/10.1021/es400782j, 2013b.

Minguillón, M. C., Perron, N., Querol, X., Szidat, S., Fahrni, S. M., Alastuey, A., Jimenez, J. L., Mohr, C., Ortega, A. M., Day, D. A., Lanz, V. A., Wacker, L., Reche, C., Cusack, M., Amato, F., Kiss, G., Hoffer, A., Decesari, S., Moretti, F., Hillamo, R., Teinilä, K., Seco, R., Peñuelas, J., Metzger, A., Schallhart, S., Müller, M., Hansel, A., Burkhart, J. F., Baltensperger, U., and Prévôt, A. S. H.: Fossil versus contemporary sources of fine elemental and organic carbonaceous particulate matter during the DAURE campaign in Northeast Spain, Atmos. Chem. Phys., 11, 1206712084, https://doi.org/10.5194/acp-11-12067-2011, 2011.

Minguillón, M., Pérez, N., Marchand, N., Bertrand, A., TemimeRoussel, B., Agrios, K., Szidat, S., van Drooge, B., Sylvestre, A., Alastuey, A., Reche, C., Ripoll, A., Marco, E., Grimalt, J., and Querol, X.: Secondary organic aerosol origin in an urban environment: influence of biogenic and fuel combustion precursors, Faraday Discuss., 189, 337-359, https://doi.org/10.1039/c5fd00182j, 2016.

Mutzel, A., Poulain, L., Berndt, T., Iinuma, Y., Rodigast, M., Böge, O., Richters, S., Spindler, G., Sipilä, M., Jokinen, T., Kulmala, M., , and Herrmann, H.: Highly oxidized multifunctional organic compounds observed in tropospheric particles: A field and laboratory study, Environ. Sci. Technol., 49, 7754-7761, https://doi.org/10.1021/acs.est.5b00885, 2015.

Müller, L., Reinnig, M.-C., Naumann, K. H., Saathoff, H., Mentel, T. F., Donahue, N. M., and Hoffmann, T.: Formation of 3methyl-1,2,3-butanetricarboxylic acid via gas phase oxidation of pinonic acid - a mass spectrometric study of SOA aging, Atmos. Chem. Phys., 12, 1483-1496, https://doi.org/10.5194/acp12-1483-2012, 2012.
Nah, T., McVay, R. C., Zhang, X., Boyd, C. M., Seinfeld, J. H., and $\mathrm{Ng}, \mathrm{N}$. L.: Influence of seed aerosol surface area and oxidation rate on vapor wall deposition and SOA mass yields: a case study with a-pinene ozonolysis, Atmos. Chem. Phys., 16, 9361-9379, https://doi.org/10.5194/acp-16-9361-2016, 2016.

Nenes, A., Pandis, S. N., and Pilinis, C.: ISORROPIA: A new thermodynamic equilibrium model for multiphase multicomponent inorganic aerosols, Aquat. Geochem., 4, 123-152, https://doi.org/10.1023/A:1009604003981, 1998.

Nguyen, T. B., Coggon, M. M., Bates, K. H., Zhang, X., Schwantes, R. H., Schilling, K. A., Loza, C. L., Flagan, R. C., Wennberg, P. O., and Seinfeld, J. H.: Organic aerosol formation from the reactive uptake of isoprene epoxydiols (IEPOX) onto nonacidified inorganic seeds, Atmos. Chem. Phys., 14, 3497-3510, https://doi.org/10.5194/acp-14-3497-2014, 2014.

Nicolas, J.: Caractérisation physico-chimique de l'aérosol troposphérique en Méditerranée : sources et devenir, Thèse de Doctorat, Univ. Versailles-Saint-Quentin-en-Yvelines, 2013.

Odum, J. R., Hoffmann, T., Bowman, F., Collins, D., Flagan, R. C., and Seinfeld, J. H.: Gas/particle partitioning and secondary organic aerosol yields, Environ. Sci. Technol., 30, 2580-2585, https://doi.org/10.1021/es950943+, 1996.

O’Dowd, C. D., Facchini, M. C., Cavalli, F., Ceburnis, D., Mircea, M., Decesari, S., Fuzzi, S., Yoon, Y. J., and Putaud, J. P.: Biogenically driven organic contribution to marine aerosol, Nature, 431, 676-680, https://doi.org/10.1038/nature02959, 2004.

O'Dowd, C. D., Langmann, B., Varghese, S., Scannell, C., Ceburnis, D., and Facchini, M.: A combined organic-inorganic sea-spray source function, Geophys. Res. Lett., 35, 101801, https://doi.org/10.1029/2007GL030331, 2008.

Pankow, J. F.: An absorption model of gas/particle partitioning of organic compounds in the atmosphere, Atmos. Environ., 28, 185-188, https://doi.org/10.1016/1352-2310(94)90093-0, 1994.

Passant, N.: Speciation of UK emissions of non-methane volatile organic compounds, AEA Technology, AEAT/ENV/0545, available at: http://uk-air.defra.gov.uk/reports/empire/AEAT_ENV_ 0545_final_v2.pdf, 2002.

Praplan, A. P., Schobesberger, S., Bianchi, F., Rissanen, M. P., Ehn, M., Jokinen, T., Junninen, H., Adamov, A., Amorim, A., Dommen, J., Duplissy, J., Hakala, J., Hansel, A., Heinritzi, M., Kangasluoma, J., Kirkby, J., Krapf, M., Kürten, A., Lehtipalo, K., Riccobono, F., Rondo, L., Sarnela, N., Simon, M., Tomé, A., Tröstl, J., Winkler, P. M., Williamson, C., Ye, P., Curtius, J., Baltensperger, U., Donahue, N. M., Kulmala, M., and Worsnop, D. R.: Elemental composition and clustering behaviour of apinene oxidation products for different oxidation conditions, Atmos. Chem. Phys., 15, 4145-4159, https://doi.org/10.5194/acp15-4145-2015, 2015.

Pun, B. K., Seigneur, C., and Lohman, K.: Modeling secondary organic aerosol formation via multiphase partitioning with molecular data, Environ. Sci. Technol., 40, 4722-4731, https://doi.org/10.1021/es0522736, 2006.

Putaud, J.-P., Raes, F., Van Dingenen, R., Brueggemann, E. Facchini, M. C., Decesari, S., Fuzzi, S., Gehrig, R., Hueglin, C., Laj, P., Lorbeer, G., Maenhaut, W., Mihalopoulos, N., Mueller, K., Querol, X., Rodriguez, S., Schneider, J., Spindler, G., ten Brink, H., Tørseth, K., and Wiedensohler, A. A.: European aerosol phenomenology-2: chemical characteristics of particulate matter 
at kerbside, urban rural and background sites in Europe, Atmos. Environ., 38, 2579-2595, 2004.

Pye, H. O. T., Chan, A. W. H., Barkley, M. P., and Seinfeld, J. H.: Global modeling of organic aerosol: the importance of reactive nitrogen $\left(\mathrm{NO}_{x}\right.$ and $\left.\mathrm{NO}_{3}\right)$, Atmos. Chem. Phys., 10, 1126111276, https://doi.org/10.5194/acp-10-11261-2010, 2010.

Pye, H., Luecken, D. J., Xu, L., Boyd, C., Ng, N., Baker, K., Ayres, B., Bash, J., Baumann, K., Carter, W., Edgerton, E., Fry, J., Hutzell, W., Schwede, D., and Shepson, P.: Modelling the current and the future roles of particulate organic nitrates in the southeastern United States, Environ. Sci. Technol., 49, 14195-14203, https://doi.org/10.1021/acs.est.5b03738, 2015.

Rattanavaraha, W., Rosen, E., Zhang, H., Li, Q., Pantong, K., and Kamens, R. M.: The reactive oxidant potential of different types of aged atmospheric particles: An outdoor chamber study, Atmos. Environ., 45, 3848-3855, https://doi.org/10.1016/j.atmosenv.2011.04.002, 2011.

Rissanen, M., Kurtén, T., Sipilá, M., Thornton, J., Kausiala, O., Garmash, O., Kjaergaard, H., Petaja, T., Worsnop, D., Ehn, M., and Kulmala, M.: Effects of chemical complexity on the autoxidation mechanisms of endocyclic alkene ozonolysis products: from Methylcyclohexenes toward understanding $\alpha$-pinene, J. Phys. Chem., 119, 4633-4650, https://doi.org/10.1021/jp510966g, 2015.

Robinson, A. L., Donahue, N. M., Shrivastava, M. K., Weitkamp, E. A., Sage, A. M., Grieshop, A. P., Lane, T. E., Pierce, J. R., and Pandis, S. N.: Rethinking Organic Aerosols: Semivolatile Emissions and Photochemical Aging, Science, 315, 1259-1262, https://doi.org/10.1126/science.1133061, 2007.

Sartelet, K., Couvidat, F., Seigneur, C., and Roustan, Y.: Impact of biogenic emissions on air quality over Europe and North America, Atmos. Environ., 53, 131-141, 2012.

Sartelet, K. N., Debry, E., Fahey, K., Roustan, Y., Tombette, M., and Sportisse, B.: Simulation of aerosols and related species over Europe with the Polyphemus system. Part I: model-todata comparison for 2001, Atmos. Environ., 41, 6116-6131, https://doi.org/10.1016/j.atmosenv.2007.04.024, 2007.

Saxena, P. and Hildemann, L. M.: Water-soluble organics in atmospheric particles: A critical review of the literature and application of thermodynamics to identify candidate compounds, J. Atmos. Chem., 24, 57-109, 1996.

Schwier, A. N., Rose, C., Asmi, E., Ebling, A. M., Landing, W. M., Marro, S., Pedrotti, M.-L., Sallon, A., Iuculano, F., Agusti, S., Tsiola, A., Pitta, P., Louis, J., Guieu, C., Gazeau, F., and Sellegri, K.: Primary marine aerosol emissions from the Mediterranean Sea during pre-bloom and oligotrophic conditions: correlations to seawater chlorophyll $a$ from a mesocosm study, Atmos. Chem. Phys., 15, 7961-7976, https://doi.org/10.5194/acp15-7961-2015, 2015.

Sciare, J., d'Argouges, O., Sarda-Estève, R., Gaimoz, C., Dolgorouky, C., Bonnaire, N., Favez, O., Bonsang, B., and Gros, V.: Large contribution of water-insoluble secondary organic aerosols in the region of Paris (France) during wintertime, J. Geophys. Res., 116, d22203, https://doi.org/10.1029/2011JD015756, 2011.

Seinfeld, J. and Pandis, S.: Atmospheric Chemistry and Physics: From Air Pollution to Climate Change, Wiley, New York, 2nd Ed., 2006.
Shrivastava, M., Cappa, C., Fan, J., Goldstein, A., Guenther, A., Jimenez, J., Kuang, C., Laskin, A., Martin, S., Ng, N., Petaja, T., Pierce, J., Rasch, P., Roldin, P., Seinfeld, J., Shilling, J., Smith, J., Thornton, J., Volkamer, R., Wang, J., Worsnop, D., Zaveri, R., Zelenyuk, A., and Zhang, Q.: Recent advances in understanding secondary organic aerosol: Implications for global climate forcing, Rev. Geophys., 55, 509-559, https://doi.org/10.1002/2016RG000540, 2017.

Sič, B., El Amraoui, L., Piacentini, A., Marécal, V., Emili, E., Cariolle, D., Prather, M., and Attié, J.-L.: Aerosol data assimilation in the chemical transport model MOCAGE during the TRAQA/ChArMEx campaign: aerosol optical depth, Atmos. Meas. Tech., 9, 5535-5554, https://doi.org/10.5194/amt-9-55352016, 2016.

Surratt, J. D., Gómez-González, Y., Chan, A. W. H., Vermeylen, R., Shahgholi, M., Kleindienst, T. E., Edney, E. O., Offenberg, J. H., Lewandowski, M., Jaoui, M., Maenhaut, W., Claeys, M., Flagan, R. C., and Seinfeld, J. H.: Organosulfate formation in biogenic secondary organic aerosol, J. Phys. Chem., 112, 83458378, https://doi.org/10.1021/jp802310p, 2008.

Surratt, J. D., Chan, A. W. H., Eddingsaas, N. C., Chan, M., Loza, C. L., Kwan, A. J., Hershey, S. P., Flagan, R. C., Wennberg, P. O., and Seinfeld, J. H.: Reactive intermediates revealed in secondary organic aerosol formation from isoprene, P. Natl. Acad. Sci., 107, 6640-6645, https://doi.org/10.1073/pnas.0911114107, 2010.

Svendby, T. M., Lazaridis, M., and Tørseth, K.: Temperature dependent secondary organic aerosol formation from terpenes and aromatics, J. Atmos. Chem., 59, 25-46, https://doi.org/10.1007/s10874-007-9093-7, 2008.

Szmigielski, R., Surratt, J. D., Gomez-Gonzalez, Y., Van der Veken, P., Kourtchev, I., Vermeylen, R., Blockhuys, F., Jaoui, M., Kleindienst, T. E., Lewandowski, M., Offenberg, J. H., Edney, E. O., Seinfeld, J. H., Maenhaut, W., and Claeys, M.: 3-methyl1,2,3-butanetricarboxylic acid: An atmospheric tracer for terpene secondary organic aerosol, Geophys. Res. Lett., 34, L24811, https://doi.org/10.1029/2007GL031338, 2007.

Troen, I. B. and Mahrt, L.: A simple model of the atmospheric boundary layer; sensitivity to surface evaporation, Bound.-Layer Meteorol., 37, 129-148, https://doi.org/10.1007/BF00122760, 1986.

Tuet, W. Y., Chen, Y., Xu, L., Fok, S., Gao, D., Weber, R. J., and Ng, N. L.: Chemical oxidative potential of secondary organic aerosol (SOA) generated from the photooxidation of biogenic and anthropogenic volatile organic compounds, Atmos. Chem. Phys., 17, 839-853, https://doi.org/10.5194/acp-17-839-2017, 2017.

Turpin, B. J. and Lim, H.-J.: Species contributions to $\mathrm{PM}_{2.5}$ mass concentrations: Revisiting common assumptions for estimating organic mass, Aerosol Sci. Technol., 35, 602-610, https://doi.org/10.1080/02786820152051454, 2001.

Warnke, J., Bandur, R., and Hoffmann, T.: Capillary-HPLCESI-MS/MS method for the determination of acidic products from the oxidation of monoterpenes in atmospheric aerosol samples, Analyt. Bioanalyt. Chem., 385, 34-45, https://doi.org/10.1007/s00216-006-0340-6, 2006.

Xing, L., Fu, T.-M., Cao, J. J., Lee, S. C., Wang, G. H., Ho, K. F., Cheng, M.-C., You, C.-F., and Wang, T. J.: Seasonal and spatial variability of the OM/OC mass ratios and high regional correlation between oxalic acid and zinc in Chinese 
urban organic aerosols, Atmos. Chem. Phys., 13, 4307-4318, https://doi.org/10.5194/acp-13-4307-2013, 2013.

Xu, X., Wang, J., Zeng, J., Spurr, R., Liu, X., Dubovik, O., Li, L., Li, Z., Mishchenko, M., Siniuk, A., and Holben, B.: Retrieval of aerosol microphysical properties from AERONET photo-polarimetric measurements. 2: A new research algorithm and case demonstration, J. Geophys. Res., 120, 7079-1098, https://doi.org/10.1002/2015JD023113, 2015.
Yarwood, G., Rao, S., Yocke, M., and Whitten, G.: Updates to the carbon bond chemical mechanism: CB05. Rep. RT-0400675, 246 pp, available at: http://www.camx.com/files/cb05_final_report_ 120805.aspx (last access: 27 March 2017), 2005.

Zhu, S., Sartelet, K., Healy, R., and Wenger, J.: Simulation of particle diversity and mixing state over Greater Paris: A modelmeasurement inter-comparison, Faraday Discuss., 189, 547-566, https://doi.org/10.1039/C5FD00175G, 2016. 